\title{
Rare Earth Elements in the Soil Environment
}

\author{
Silvio J. Ramos ${ }^{1}$ - Guilherme S. Dinali ${ }^{2}$ Cynthia Oliveira ${ }^{2}$ - Gabriel C. Martins ${ }^{2}$ • \\ Cristiano G. Moreira ${ }^{2}$ - José O. Siqueira ${ }^{3} \cdot$ Luiz R. G. Guilherme $^{2}$
}

Published online: 25 February 2016

(C) Springer International Publishing AG 2016

\begin{abstract}
Rare earth elements (REE) are a homogenous group of 17 chemical elements in the periodic table that are key to many modern industries including chemicals, consumer electronics, clean energy, transportation, health care, aviation, and defense. Moreover, in recent years, they have been used in agriculture. One of the consequences of their worldwide use is the possible increase of their levels in various environmental compartments. This review addresses major topics concerning the study of REE in the soil environment, with special attention to the latest research findings. The main sources of REE to soils, the contents of REE in soils worldwide, and relevant information on the effects of REE to plants were explored. Ecological and human health risk issues related to the presence of REE in soils were also discussed. Although several findings reported positive effects of REE on plant growth, many questions about their biological role remain unanswered. Therefore, studies concerning the actual mechanism of action of these elements on cellular and physiological processes should be further refined. Even more urgent is to unveil their chemical behavior in soils and the ecological and human health risks that might be associated with the widespread use of REE in our modern society.
\end{abstract}

This article is part of the Topical Collection on Land Pollution

Luiz R. G. Guilherme guilherm@dcs.ufla.br

1 Vale Institute of Technology - Mining, Avenida Juscelino Kubitschek, 31, Ouro Preto, Minas Gerais 35400-000, Brazil

2 Soil Science Department, Federal University of Lavras, Lavras, Minas Gerais 37200-000, Brazil

3 Vale Institute of Technology — Sustainable Development, Rua Boaventura da Silva, 955, Belém, Pará 66055-090, Brazil
Keywords Lanthanides · Fertilizers · Bioavailability · Bioaccessibility $\cdot$ Environmental safety $\cdot$ Risk assessment

\section{Introduction}

Rare earth elements (REE) are identified by the International Union of Pure and Applied Chemistry (IUPAC) as a group of 17 elements with similar physicochemical characteristics. Of these elements, 15 belong to the group of lanthanides with atomic numbers between $Z=57$ and $Z=71$, as follows: lanthanum $(\mathrm{La})$, cerium $(\mathrm{Ce})$, praseodymium $(\mathrm{Pr})$, neodymium $(\mathrm{Nd})$, promethium $(\mathrm{Pm})$, samarium $(\mathrm{Sm})$, europium $(\mathrm{Eu})$, gadolinium (Gd), terbium (Tb), dysprosium (Dy), holmium (Ho), erbium (Er), thulium (Tm), ytterbium $(\mathrm{Yb})$, and lutecium $(\mathrm{Lu})$. Two more elements join them: scandium $(\mathrm{Sc}, \mathrm{Z}=21)$ and yttrium $(\mathrm{Y}, \mathrm{Z}=39)$ [1]. The REE are commonly divided into two distinct groups: light (LREE) and heavy (HREE). The LREE are $\mathrm{La}, \mathrm{Ce}, \mathrm{Pr}, \mathrm{Nd}, \mathrm{Pm}$, and $\mathrm{Sm}$. They are found in higher amount in the environment, present smaller atomic masses, besides higher solubility and alkalinity. The following elements are part of the HREE group: $\mathrm{Eu}, \mathrm{Gd}, \mathrm{Tb}, \mathrm{Dy}, \mathrm{Ho}, \mathrm{Er}, \mathrm{Tm}, \mathrm{Yb}, \mathrm{Lu}$, and Y. These elements have higher atomic masses, smaller solubility, and alkalinity [2]. However there is no absolute definition in the scientific community worldwide to classify each element within the group of LREE or HREE.

Since the first report of rare earth element (REE) detection in apatites of sedimentary and biological origins, as well as in barley, beechwood, and rice and in the leaves of tobacco and grape in 1878 [3], there has been an increasing interest for the study of REE in the soil environment. Yet, our understanding of the biological role of REE is still in its early stages [4], which reinforces the need for continuous research to better understand the environmental effects of REE enrichment of 
soils as a consequence of their increasing use in industrial and agricultural practices.

A survey of the Web of Science database (2015 Jun 14) showed that the scientific literature comprised 1205 references (including 46 patents) on studies of REE in soils using the following keywords: "rare earth elements" AND "soil." Half of the references (603) were published in the last 6 years (since 2009 ), and $\sim 56 \%$ of them were concentrated in five countries: China (with $\sim 27 \%$ of the references), USA, France, Japan, and Germany. This survey was further refined by entering the keyword "pollution" (rare earth elements AND soil AND pollution), leading to a subset of 260 references. Again, the great majority of the references $(\sim 57 \%)$ were published in recent years (since 2010), and half of them (130) came from China, Japan, Germany, and France. By replacing the third keyword with "plant" (rare earth elements AND soil AND plant), we collected 369 references, and when we added pollution to this last refinement (rare earth elements AND soil AND plant AND pollution), we have recovered only 91 references from the previous search, with $\sim 57 \%$ published since 2010 . Lastly, by using a combination of keywords rare earth elements AND soil AND "risk assessment," we found only 15 references that corresponded to our search criteria.

From the previous information, it is clear that research with REE in soils has been concentrated mostly in the last 5-6 years and only in a few countries. It is also noteworthy that studies with REE in soils with a focus on their effect in plants and in the environment are still limited. Finally, we certainly could conclude that studies focusing on risk assessment of REE in the soil environment are an urgent need, taking into consideration the increasing worldwide use of REE in recent years.

This review was prepared in order to address relevant information (published preferentially in the last 5-6 years) concerning REE in the soil environment, with a focus on the following: (1) the main sources of REE to soils; (2) the major factors affecting the content of REE in soils worldwide; and (3) relevant information on the effects of REE to living systems, with a focus on plant studies and on the need for urgent investigations related to risk assessment of REE in the soil environment (Fig. 1).

\section{Discovery and Occurrence of REE}

The history of the discovery of REE is a complex subject full of controversy. In one of the versions, which started in 1787, Carl Axel Arrhenius discovered a heavy black mineral in a trip near the village of Ytterby in the Island of Resarö (east of Stockholm). In 1794, the Finnish professor of chemistry and mineralogy Johan Gadolin analyzed a sample of this mineral provided by Arrhenius and found a new "earth," naming it Ytterby. Years later, the Swedish chemist Anders Gustav Ekeberg renamed this earth as yttrium. In another version, it is affirmed that the first registration occurred in 1751, when the Swedish chemist Axel
Frederik Cronstedt discovered a heavy rock in the Bastnas mine in Sweden, in which Martin Heinrich Klaproth and Jons Jacob Berzelius, along with Wilhelm Hisinger later in 1803, isolated an earth that they named cerium. Thus, in the beginning of the nineteenth century, two REE were known "yttrium" (discovered in 1794) and "cerium" (discovered in 1803) [5]. As time passed and new technologies were developed, it was found out that these two earths (yttrium and cerium) were a complex mixture of other elements. Currently, the rare earth family consists of 17 transition metals located in group 3 of the periodic table.

The abundance of REE in the earth crust is significant. In contrast with its denomination, the REE are not necessarily rare, because they are found in almost all rock formations [6]. Cerium is the most abundant REE and the 25th most abundant element in earth's crust [7]. The lanthanides found in smaller concentrations - $\mathrm{Lu}$ and $\mathrm{Tm}$ - are more abundant in the earth crust than cadmium (Cd) and selenium (Se) [8]. Pm is the only artificial element, which is, it does not occur naturally in earth's crust $[9,10]$.

Known reserves of REE (approximately 130 million tons) are extensively distributed worldwide. They occur in 6 European countries, 14 Asian countries, and 10 African countries, as well as in the USA, Canada, Australia, and Brazil [11]. China has the largest reserves (approximately 55 million tons) and appears as the world's largest REE producer (about $86 \%$ of the production). Brazil is the second country in REE reserves (approximately 22 million tons), followed by Australia, with approximately 3.2 million tons [12].

\section{Characteristics and Uses of REE}

The REE are very similar chemically and physically, and this uniformity comes from the nature of their electronic configuration, generally reaching an oxidation state " +3 ," particularly stable, and a small but constant reduction in the ionic radius, with an increase of the atomic number, which is called "lanthanide contraction" [7]. Elements $\mathrm{Ce}$ and Eu can also be present in oxidation states " +4 " and " +2 ," respectively $[7,13]$. The REE are soft elements, malleable, ductile, and considered great electrical conductors, which allow their application in several industrial segments of high technology, such as automotive, nuclear, petroleum, electronic, military, metallurgical, and renewable energy [14-17]. REE can also be applied in studies of pedogenic processes, as tracers in geochemical studies [18, 19], and in agricultural fertilizers [20].

Regarding their natural distribution, the REE show regularity and follow the Oddo-Harkins rule, in which elements with an even atomic number (Ce, Nd, Sm, Gd, Dy, Er, and $\mathrm{Yb}$ ) are more abundant than elements with an odd atomic number (La, $\mathrm{Pr}, \mathrm{Eu}, \mathrm{Tb}, \mathrm{Ho}, \mathrm{Tm}$, and $\mathrm{Lu}$ ), besides having decreasing contents with an increase in atomic mass [9]. This Oddo-Harkins rule refers to a "zigzag" standard in diagrams of composition- 
Fig. 1 Graphical illustration of the sources of rare earth elements (REE) to soils (picture on the left shows the mineral apatite), where REE may undergo a series of reactions in the soil profile prior to entering the main environmental compartments

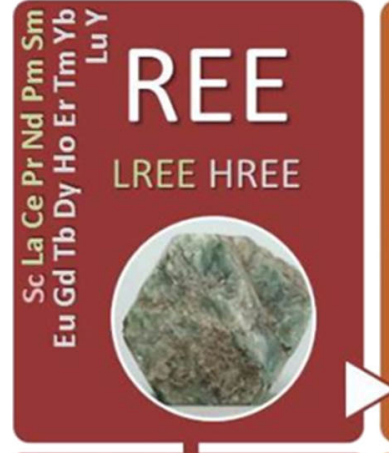

Weathering Mining/Processing Uses
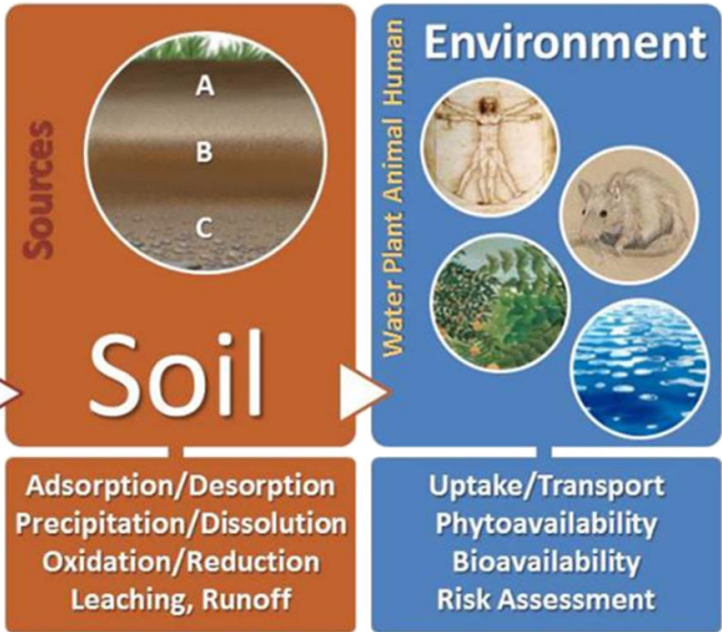

abundance, in which REE are normally presented. This standard comes from the variable concentrations that these elements have due to the inconstancy in their atomic nuclei, where the elements with even atomic numbers, by having a proton pairing in their chemical distribution, are more stable than their odd periodic neighbors [21].

In order to eliminate this zigzag standard effect and graphically demonstrate the behavior of REE in the environment, the normalization of their contents is done in the study sample, through recognized standards [22], as shown in Fig. 2. This tool helps in comprehending analytical results and allows the identification of possible abnormalities, when normalized. Several standards are used for this purpose, with the chondrite meteorites being the most used, since they are considered materials that have the same chemical composition of the material that originated the solar system bodies [24]. Besides the chondrite meteorites [23], other standards are also used such as the upper continental crust [25], the North American shale composite [26], and the Post-Archean Australian shales [27].

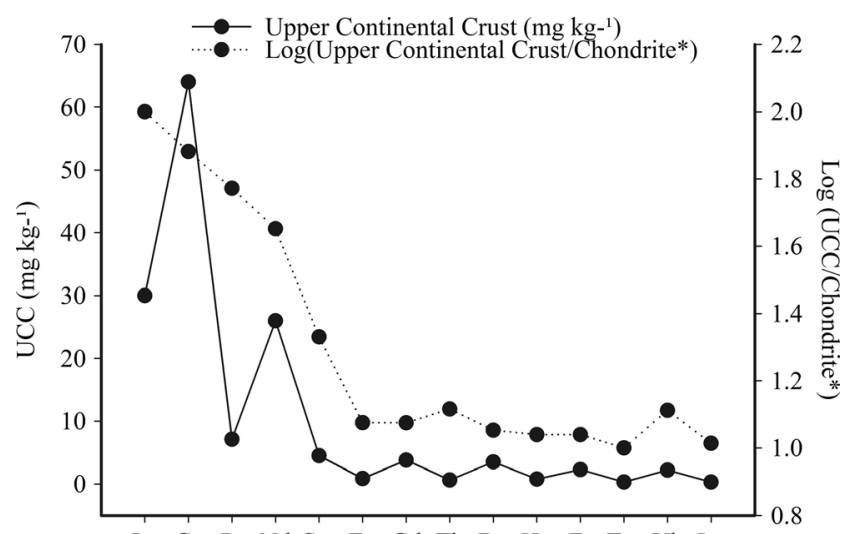

La Ce Pr Nd Sm Eu Gd Tb Dy Ho Er Tm Yb Lu

Fig. 2 Concentration $\left(\mathrm{mg} \mathrm{kg}^{-1}\right)$ of rare earth elements in the upper continental crust and chondrite normalization of REE in UCC. Asterisk: data from [23]

\section{Sources and Fate of REE in Soils}

\section{Sources}

REE are found in more than 270 minerals - either primary or secondary-in a wide range of concentrations $[16,28]$. Despite this, $95 \%$ of all mineral resources containing REE in the world are concentrated in only three minerals: bastnasite, monazite, and xenotime [29].

The REE mineral content is directly proportional to its valence and ionic radius, with LREE occupying sites with the largest coordination numbers, while HREE occupy the smallest coordination numbers [30]. When a mineral has REE, it can normally contain all REE, but in different proportions and with a predominance of $\mathrm{Ce}$ and $\mathrm{La}[29,31]$.

As many metals, the REE have affinity for oxygen and are therefore found many times in phosphatic minerals, as well as in carbonates, fluorides, and silicates [8, 32-34]. Phosphatic minerals can contain high REE concentrations, which are directly related to the mineral genesis $[8,35,36]$. However, there is a difference between LREE and HREE as regard to their enrichment in phosphatic minerals, with a predominance of a negative anomaly of $\mathrm{Ce}[37,38]$. Of the phosphatic minerals, monazite contains the highest concentration of REE, with LREE being preferentially incorporated in its structure; while in xenotime, the HREE are preferentially accommodated in its structure [39].

The availability of REE in the environment under natural conditions depends on the parent material, as well as on geochemical and biological processes [40-42]. It is known that mineral weathering is an important source of elements to the soils [43]. However, even after weathering of primary minerals, REE can still, partially or totally, be again incorporated in secondary minerals, remaining immobilized [44].

The fast increase in the exploration of mineral resources that contain REE, along with their constant application in the modern industry and everyday life, can contribute to an 
increase of these elements in ecosystems [45]. The main areas with an increase of REE in the soil are restricted to regions where the agriculture is intense, to zones next to polluted sites (large cities), and/or where the parent material presents high contents of REE [46]. Industrial activities have been related with an increase of REE in soils, mainly in locations next to industrial centers $[47,48]$.

In agricultural areas, the main REE entrance is caused by application of phosphate fertilizers. This occurs because phosphatic rocks can present elevated concentrations of REE in their composition. Apatite is the main mineral explored for production of phosphate fertilizers, and the occurrence of REE in apatites from sedimentary and biological origin was first reported in 1878 [1]. The general formula for apatite is $\mathrm{Ca}_{10}\left(\mathrm{PO}_{4}\right)_{6} \mathrm{X}_{2}$, in which $\mathrm{X}$ can be fluoride, chlorine, or hydroxyl. Calcium can be substituted mainly by $\mathrm{Na}, \mathrm{Sr}, \mathrm{Mn}$, and REE. The most common substitution is $\mathrm{P}$ by $\mathrm{Si}$, along with a substitution of Ca by ions of trivalent REE [30].

Indirect application of REE to agricultural soils is a widespread practice, due to the use of phosphate fertilizers. However, in China, REE are deliberately applied to soils due to the enrichment of fertilizers with such elements. Since the 1980s, these fertilizers have been commonly applied in agriculture to increase seed germination, root growth, chlorophyll content, plant resistance, and agricultural productivity [20]. The amount of REE used in Chinese agriculture has been increasing year after year, reaching some thousands of tons per year. In this country, there are basically three types of fertilizers containing REE: (1) Changle (nitrates), (2) Nongle (chloride and oxides), and (3) MAR (complex with amino acids) [10, 45].

Table 1 shows REE contents reported in the worldwide literature for the main phosphate fertilizers and other products of relevant use in agriculture. It is noteworthy that phosphate products can present a great variability in their REE concentrations. Actually, due to the different sources (raw material) used for production of phosphate fertilizers, it is not uncommon to see that the same product may present different REE contents; e.g., a simple superphosphate produced in Pakistan has an average concentration of $40.2 \mathrm{mg} \mathrm{Ce} \mathrm{kg}^{-1}$, differing from the same product produced in Brazil, which had $1499 \mathrm{mg} \mathrm{Ce} \mathrm{kg}{ }^{-1}$. This huge variation in REE content of phosphate products occurs not only due to differences in the raw material (elemental composition of the phosphate rock), but also due to variations in rock processing operations for obtaining the final product $[53,56]$.

A ballpark assessment of the importance of phosphate fertilizers as a source of REE for agricultural ecosystems could be used taking Brazil as an example: if we consider the apparent consumption of the main phosphate fertilizers in Brazil in $2014^{1}$ ( $\sim 4.2$ million tons of monoammonium phosphate

\footnotetext{
${ }^{1}$ Personal communication from ANDA, The Brazilian Fertilizer Industry Association.
}

(MAP), 5.2 million tons of single superphosphate (SSP), and 1.8 million tons of triple superphosphate (TSP)) and the concentrations reported for cerium ( $\mathrm{mg} \mathrm{kg}^{-1}$ ) in Table 1 (449 for MAP, 1499 for SSP, and 1332 for TSP), it is estimated that the use of these fertilizers added approximately $12,000 \mathrm{t}$ of $\mathrm{Ce}$ to Brazilian soils, only in 2014. This is not too much beyond the amounts estimated for annual consumption of important micronutrients (e.g., boron, copper, manganese, and zinc) in Brazilian agriculture.

As it was seen, the fertilizers employed in agriculture are important diffuse sources of REE for soils, even unintentionally, as it occurs in countries that are great consumers of phosphate fertilizers, such as Brazil. This might be even more relevant in the case of a deliberate enrichment of fertilizers with REE, as it occurs in China.

\section{Soil Behavior}

It is well known that the bioavailability, toxicity, and deficiency of any element in the environment depend on the element's own characteristics and the soil capacity to release it from the mineral phase or colloidal fraction. The adsorption of La, Y, $\mathrm{Pr}$, and $\mathrm{Gd}$ depends on $\mathrm{pH}$ and soil cationic exchange capacity (CEC), and the availability of $\mathrm{La}, \mathrm{Ce}, \mathrm{Gd}$, and $\mathrm{Y}$ increases with a decrease in $\mathrm{pH}$ and redox potential [58, 59].

The adsorption of REE in soils is also influenced by clay type and content, especially the concentrations of aluminum silicates and iron and manganese oxides, with these last ones having the greatest adsorption capacity [10]. Sorption of La in the surface of oxides of manganese and titanium and also in iron oxy-hydroxides varies with $\mathrm{pH}$ and the type of adsorbent, occurring preferably as surface precipitation, in the case of $\mathrm{Mn}$ oxides, and in the form of monomeric or small-molecularweight complexes, in the surface of Ti and Fe oxides, demonstrating that mineralogy is crucial in REE behavior in soils $[60,61]$.

There is also a difference concerning light and heavy REE behavior in soil, with LREE being mainly associated to clayey soils, whereas HREE are more associated to sandy soils [62]. This occurs because HREE are more associated to refractory minerals (e.g., zircon), which are more resistant to weathering, and therefore remain in the coarser fraction of the soil [63].

Regarding the bond to the soil organic matter, the REE behave in a manner similar to other trace elements. Organic matter has fundamental importance in adsorption of REE, since it is a provider of negative charges to weathered soils [64]. However, it was also observed that the soluble organic fraction is responsible for REE desorption in soil, with compounds such as EDTA being able to promote the desorption of these elements, which is proportional to the concentration of acid in solution [65].

The stability of REE bonding with humic substances varies according to a molar ratio between the REE and dissolved 
Table 1 Worldwide contents of selected REE reported for major phosphate fertilizers and other particular agricultural inputs

\begin{tabular}{|c|c|c|c|c|c|c|c|c|c|}
\hline Product & $\begin{array}{l}\mathrm{La} \\
\mathrm{mg} \mathrm{kg}^{-1}\end{array}$ & $\mathrm{Ce}$ & $\mathrm{Nd}$ & $\mathrm{Sm}$ & $\mathrm{Eu}$ & $\mathrm{Tb}$ & $\mathrm{Sc}$ & Country & Source \\
\hline Single superphosphate (SSP) & 18.4 & 40.2 & - & 2.0 & 0.4 & 0.3 & - & \multirow[t]{2}{*}{ Pakistan } & \multirow[t]{2}{*}{ [49] } \\
\hline NPK $(08: 23: 18)$ & 90 & 129 & - & 12 & 3.0 & 1.5 & - & & \\
\hline Limestone & 19.5 & 10.4 & - & \multirow[t]{2}{*}{1.6} & 0.2 & - & 0.2 & \multirow[t]{2}{*}{ Egypt } & \multirow[t]{2}{*}[50]{} \\
\hline Superphosphate & 18 & 8.5 & - & & 0.3 & - & 3.9 & & \\
\hline Superphosphate & 17 & 35 & 23.5 & - & - & - & - & Bulgaria & {$[51]$} \\
\hline NPK (12:12:17) & 500 & 600 & 181 & 33.2 & 9.9 & 3 & - & Spain & {$[52]$} \\
\hline NPK (4:14:08) & 534 & 1181 & 571 & 77 & 17.1 & 4.5 & 15.2 & \multirow[t]{3}{*}{ Brazil } & \multirow[t]{3}{*}[53]{} \\
\hline SSP & 674 & 1499 & 770 & 122 & 32.5 & 6.5 & 24.6 & & \\
\hline Thermophosphate & 755 & 1575 & 748 & 105 & 24.5 & 8.3 & 23.9 & & \\
\hline Phosphoric acid & 18.7 & 16.5 & 14.2 & 0.9 & 0.8 & 2.5 & 9.3 & USA & {$[54]$} \\
\hline Phosphate rock & 2319 & 5468 & 1720 & 245 & 67 & 12 & - & \multirow[t]{2}{*}{ Brazil } & \multirow[t]{2}{*}[55]{} \\
\hline Phosphogypsum & 1484 & 3015 & 970 & 150 & 37 & 6 & - & & \\
\hline Monoammonium phosphate (MAP) & 177 & 449 & 234 & 43 & 13.6 & 8.7 & - & \multirow[t]{2}{*}{ Brazil } & \multirow[t]{2}{*}[56]{} \\
\hline Triple superphosphate (TSP) & 727 & 1332 & 556 & 89 & 29 & 13.7 & - & & \\
\hline Apatite concentrate & 1514 & 4204 & 1738 & 293 & 24.5 & 28.9 & - & Iran & {$[14]$} \\
\hline Fertilizer enriched with REE & 15,400 & 24,100 & 1100 & 2000 & 200 & 25.8 & - & China & {$[57]$} \\
\hline
\end{tabular}

organic carbon, and in these conditions, REE concentrations in solution are inversely correlated with soil $\mathrm{pH}$ and directly correlated with dissolved organic carbon concentrations [66, 67].

\section{Soil Reference Concentrations}

The knowledge of natural contents of an element in the soil (background concentration) is crucial for ecological and human health risk assessments. Regarding REE, this aspect deserves a special attention, because our understanding on the biological role of these elements is still in its early stages [2] and little is known about their effects in ecosystem function, which is especially relevant in areas affected by anthropogenic activities that alter natural concentrations of REE in soils.

Contents of REE naturally found in soils basically depend on the parent material, decreasing as follows: granite $>$ basalt $>$ sandstone [68]. Soils originated from igneous rocks, schists, and sandstone tend to contain more REE when compared to those originated from other materials [41]. Increased REE contents in areas affected by anthropogenic alterations are usually a result of the application of agricultural fertilizers [49, 52, 53, 56, 69, 70]. However, environmental factors such as rain, snow, and wind transport can contribute to these contents, mainly in areas close to large industrial sites [47].

Information is still scarce in the literature about background concentrations of REE in soils, mainly when compared with data available for many trace elements of environmental interest, such as $\mathrm{Cd}, \mathrm{Pb}, \mathrm{Cr}$, and As. Table 2 presents reference values (natural or non-natural) for REE in soils found in several countries, as well as information regarding the method used to quantify and qualify these elements, which can be an additional reason for a large variability found in REE reference values for soils worldwide.

Even though there are several techniques to quantify REE, the literature demonstrates that inductively coupled plasma mass spectrometry (ICP-MS) is the most used technique to determine REE in soils (Table 2). ICP-MS has a superior detection capability and presents elevated precision, currently being the most adequate technique for quantification of REE in soil extracts, either those obtained directly following an acid extraction or via a previous alkaline fusion of the materials to be analyzed [92-94].

Data from Table 2 revealed that $\mathrm{La}$ and $\mathrm{Ce}$ are the most abundant REE found in soils, with average concentrations as high as 123 and $273 \mathrm{mg} \mathrm{kg}^{-1}$, respectively, found in soils from Uganda. These results agreed with previous reports that Ce, followed by La, is the most abundant REE in earth's crust [41]. For the sum of LREE, the highest values were found in samples from Cape Verde, followed by Bhutan. In these countries, REE contents in soils were assessed with instrumental neutron activation analysis (INAA), which could have contributed to the higher averages. The literature reports that INAA can overestimate REE values in geological samples and therefore is not the most indicated technique for REE determination, mainly for LREE [95], although INAA is used for REE determination in soil and rock samples [96]. However, these results can also be connected to the material that originated these soils.

Table 2 reveals also that samples from soils analyzed in several European countries presented very similar average values for all REE, with Denmark being an exception. The average value of the sum of REE contents ( $\mathrm{REE}$ ) was higher for Croatia (216 $\mathrm{mg} \mathrm{kg}^{-1}$ ) and smaller for Denmark 


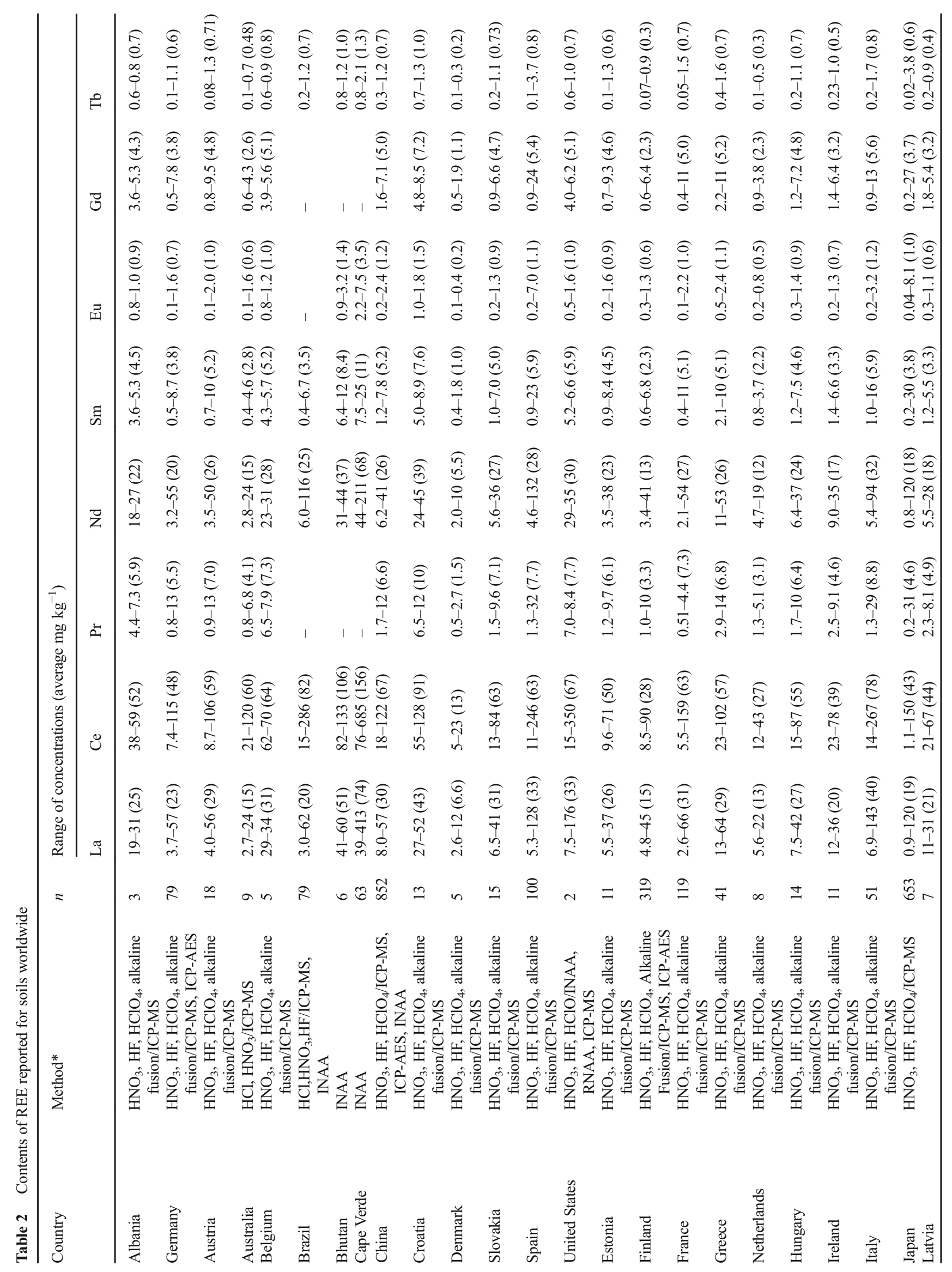




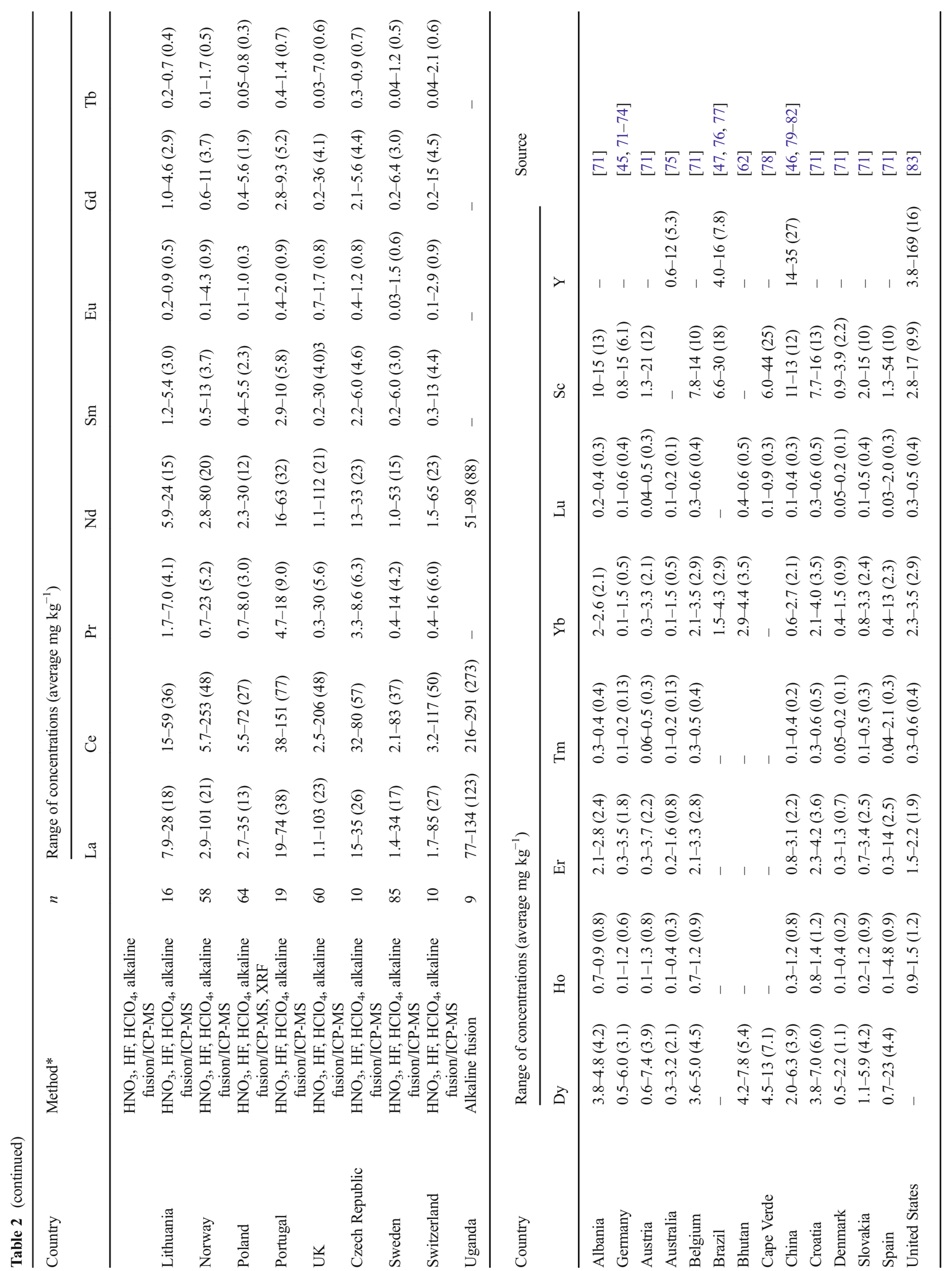




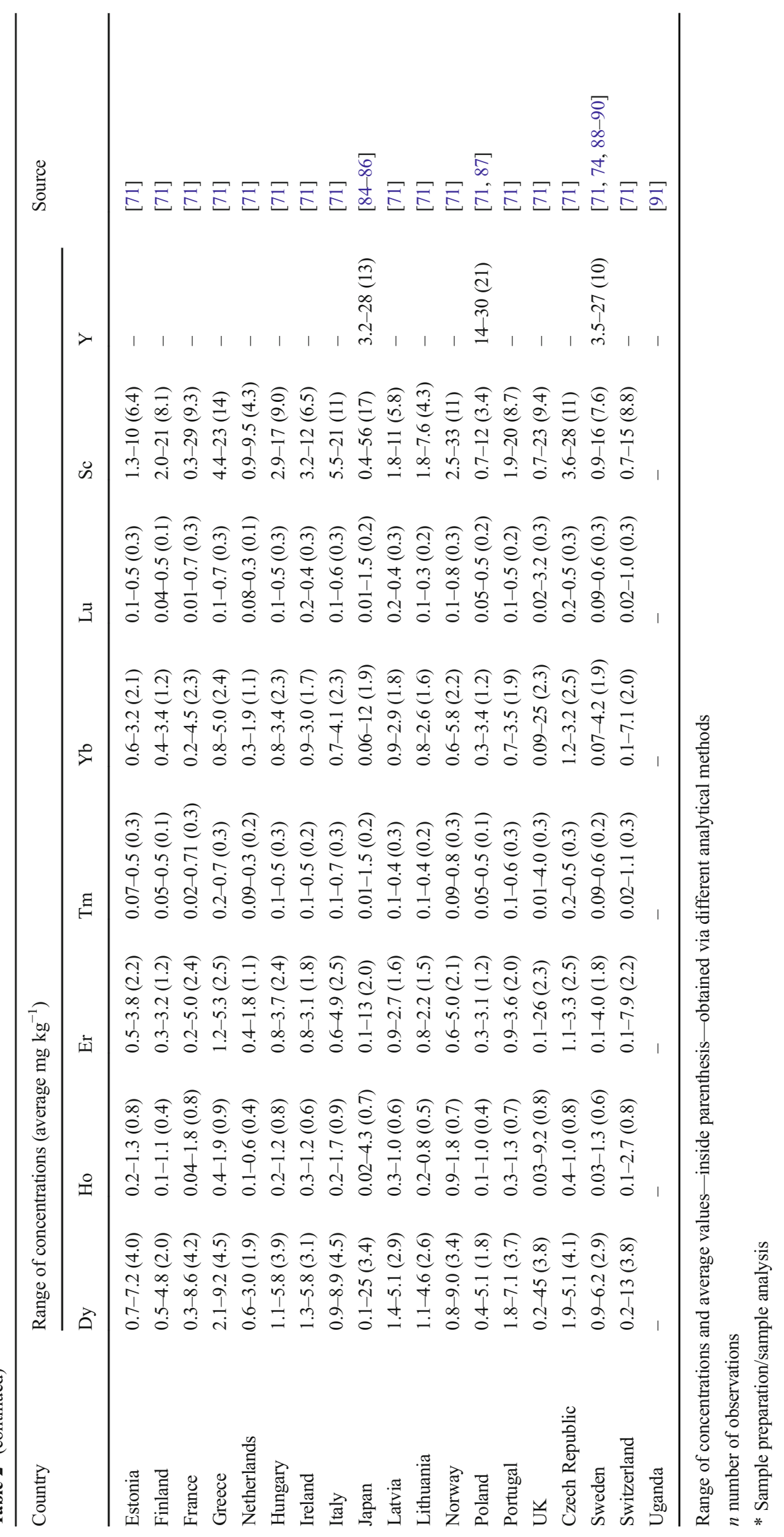


(32 $\mathrm{mg} \mathrm{kg}^{-1}$ ). Since phosphate fertilizers are one of the main diffuse sources of REE to soils [46, 97, 98], we could expect higher average $\Sigma$ REE for soils of France, Spain, and the UK, which are historically the major consumers of phosphate fertilizers in Europe $\left(\mathrm{P}_{2} \mathrm{O}_{5}\right.$ consumption taken from IFA database - www.fertilizer.org/statistics). However, this was not observed. Data from Table 2 suggests that the sources and the behavior of REE in European soils tend to be very similar.

In order to evaluate a potential influence of the addition of phosphate fertilizers over the content of REE in European soils, the data collected for European countries (Table 2), as well as the contents of REE from Upper Continental Crust and from an apatite of sedimentary origin (main raw material used in the production of phosphate fertilizers marketed in Europe), were normalized to a standard material, i.e., the average REE concentrations found in chondrites, as proposed by [23] (Fig. 3).

The REE signatures for European soils are very similar to that of the Upper Continental Crust (UCC), which, by its turn, differs from the typical signature of an apatite of sedimentary origin derived from Morocco, a large exporter of phosphate fertilizers to Europe. The fact that the typical signature of the Morocco apatite is distinct from those observed for European soils (Fig. 2) indicates that even though phosphate fertilizers are considered the main diffuse source of REE to the environment, its intense and continuous application in Europe was not enough to alter the typical signature of these elements in the soils. Actually, Fig. 2 reveals not only that the current status of REE in European soils was not affected by intense anthropogenic activity caused by continuous additions of REE from phosphate fertilizers, but also indicates that REE concentrations in European soils are compatible with the global average.

Finally, with respect to yttrium (Y), even though this element is recognized as a REE, there is little information in the literature regarding reference concentrations of this element in soils. Values for Y in soil were found only in studies done in seven countries, with averages varying from $5.3 \mathrm{mg} \mathrm{kg}^{-1}$, in Australia, to $27 \mathrm{mg} \mathrm{kg}^{-1}$, in China.

\section{REE in Plants}

Since the 1970s, there are reports of commercial application of REE in Chinese agriculture, with indication of yield increases in several crops [100,101].

Many hypotheses have been currently proposed for REE effects on plant growth and development, not only at the metabolic level, but also at the structural and cytogenetic levels [102-104]. Hypotheses supporting the beneficial effects of REE in plant metabolism include stimulation of the antioxidant system, increased nutrient absorption, increased nitrogen and $\mathrm{CO}_{2}$ fixation, and positive effects on biomass production by induction of a higher photosynthetic rate, due to an increase in electron transport rate in the photochemical phase of photosynthesis [105]. Regarding the plant structural level, the hypotheses vary from the substitution of $\mathrm{Ca}$ in cell wall structure, in cytoskeleton, and in membranes and cytoplasmatic organelles [106, 107], to modifications in size and density of anatomic structures such as stomata, trichomes, and tissue thickness [103]. At the cytogenetic level, the REE-associated benefits are linked to an increase in the mitotic index [102,

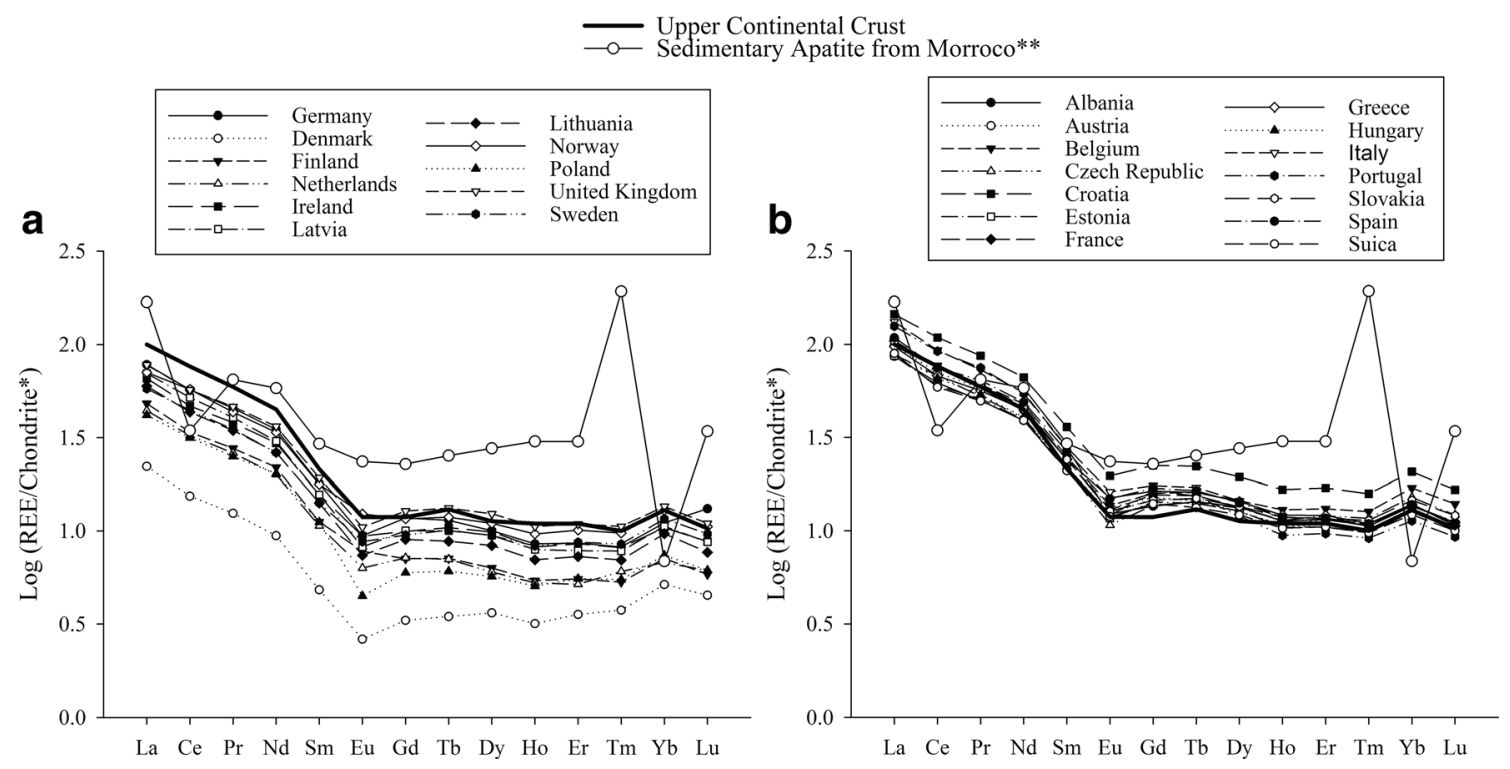

Fig. 3 Chondrite normalized REE distribution patterns of UCC compared with a sedimentary apatite from Morocco and with average values of soils from different European countries. Countries on the left

(a) show a trend of REE depletion in soils relative to UCC, whereas countries on the right (b) show a trend of REE enrichment relative to UCC. Single asterisk: data from [23]; double asterisk: data from [99] 
104], as well as to the development of abnormalities in the cell cycle that benefit the production of biomass, such as the appearance of binucleated cells [102]. Some REE action mechanisms in plants, as well as effects found in recent studies, are reported in the following topics, with data compiled in Table 3.

\section{REE Uptake, Distribution, and Contents in Plants}

REE concentrations in plants vary according to the contents of these elements in the environment and among different plant species [121]. Due to their higher mobility in soils, LREE are more easily absorbed by plants, thus occurring at greater contents than HREE in plant tissues. In fact, citrus plants have recently being described as REE bioaccumulators, accumulating especially LREE [144]. In addition, since HREE form much more stable complexes in soil solution, preferential absorption of LREE is favored [145].

Other factors affecting REE uptake in soil solution are the levels of nitrogen, potassium, and phosphate fertilization. REE absorption is facilitated following an increase in the rates of nitrogen and potassium fertilization, while phosphate fertilization renders the absorption of these elements more difficult [146].

Plants have a range of features that affect REE redistribution, especially those related to the presence of apoplastic barriers. Initially, the apoplastic barriers situated in the roots are the first obstacles for these elements to reach the xylem, thus impairing their translocation to remaining plant organs. Due to this fact, the contents of REE found in different plant organs follow the sequence: roots $>$ stems $>$ leaves $>$ flowers $>$ fruit $>$ seeds [140, 145].

REE absorption occurs also thru foliar applications. Under these circumstances, the apoplastic barriers continue to work as obstacles to the translocation of these elements to different plant parts. However, in this case, the distribution of these elements follows the order: leaves $>$ stems $>$ roots $>$ flowers $>$ fruit $>$ seeds [145].

Within the saps of the xylem or phloem, where REE are translocated/remobilized, the redistribution is generally regulated by mechanisms that control the nutrient flow, i.e., the transpiratory rate, in the case of the xylem, and the sourcedrain system (osmosis control), in the case of the phloem. Inside the vascular tissues, the REE can bind reversibly to anions such as $\mathrm{COOH}^{-}$, with the degree of bonding varying according to the atomic number of the element of interest [97], which may also influence the accumulation of these elements [97, 147]. Inside the plants, most REE are bonded to cell walls $[106,148]$. However, some REE can cross the cell membrane, accumulating in organelles as crystals such as "REE oxalates" $[102,107]$ or even in root cortical tissues, which also avoids translocation to plant shoots.
As seen, the effects of REE on plants can be either direct, due to their presence in plant structures, or indirect - mainly in the shoot-for triggering processes through secondary messengers that cause a cascade effect on metabolic processes. Owing to this fact, plant processes affected by the presence of REE are quite complex and still need to be better elucidated. Some effects of REE on plant metabolism, development, and anatomy are described in the next sections, with detailed information provided in Table 3.

\section{Effects of REE on Plant Metabolism}

\section{Water Use Efficiency}

It has been reported that REE have a positive effect on water use efficiency by plants due to an increase in the content of proline, an amino acid with a high ability for hydration, which makes the plant more resistant to water stresses [108, 110, 111]. There are also studies reporting the advantages of increased proline content in the presence of REE, eliminating reactive oxygen species (ROS) and promoting the inhibition of lipid peroxidation [109, 112].

\section{Photosynthesis (Photochemical Phase)}

Since REE have the chemical property of electric conductors, being therefore used in several industry sectors, there is a hypothesis that this chemical property can also leverage electronic flow processes in plant species [105]. The performance of REE as electron conductors in plants could be associated with the photosynthesis $\mathrm{Z}$ scheme, i.e., with the photochemical phase of photosynthesis. In this manner, REE can increase the electronic flow in the photochemical phase, decreasing energy dissipation to other processes besides the photosynthetic. REE can also increase the potential quantum yield of photosystem II, allowing that the larger electronic flow, caused by REE, be used for production of a greater amount of energy and reducing power, favoring the whole photosynthetic process, and consequently the biomass production in plants [105, 113-115].

\section{Photosynthesis (Biochemical Phase)}

The energy increase and the reducing power generated by the photochemical phase of photosynthesis, in the presence of REE, favor also the biochemical phase of photosynthesis. However, besides this stimulus from a higher reducing power and increased energy available for Calvin cycle reactions, the REE can leverage gas exchanges, especially the stomatal conductance, which increases the photosynthetic rate, due to a higher $\mathrm{CO}_{2}$ assimilation for the photosynthetic process [102, $118]$. It is also broadly reported that besides favoring the photosynthesis through increasing gas exchanges, REE increase 


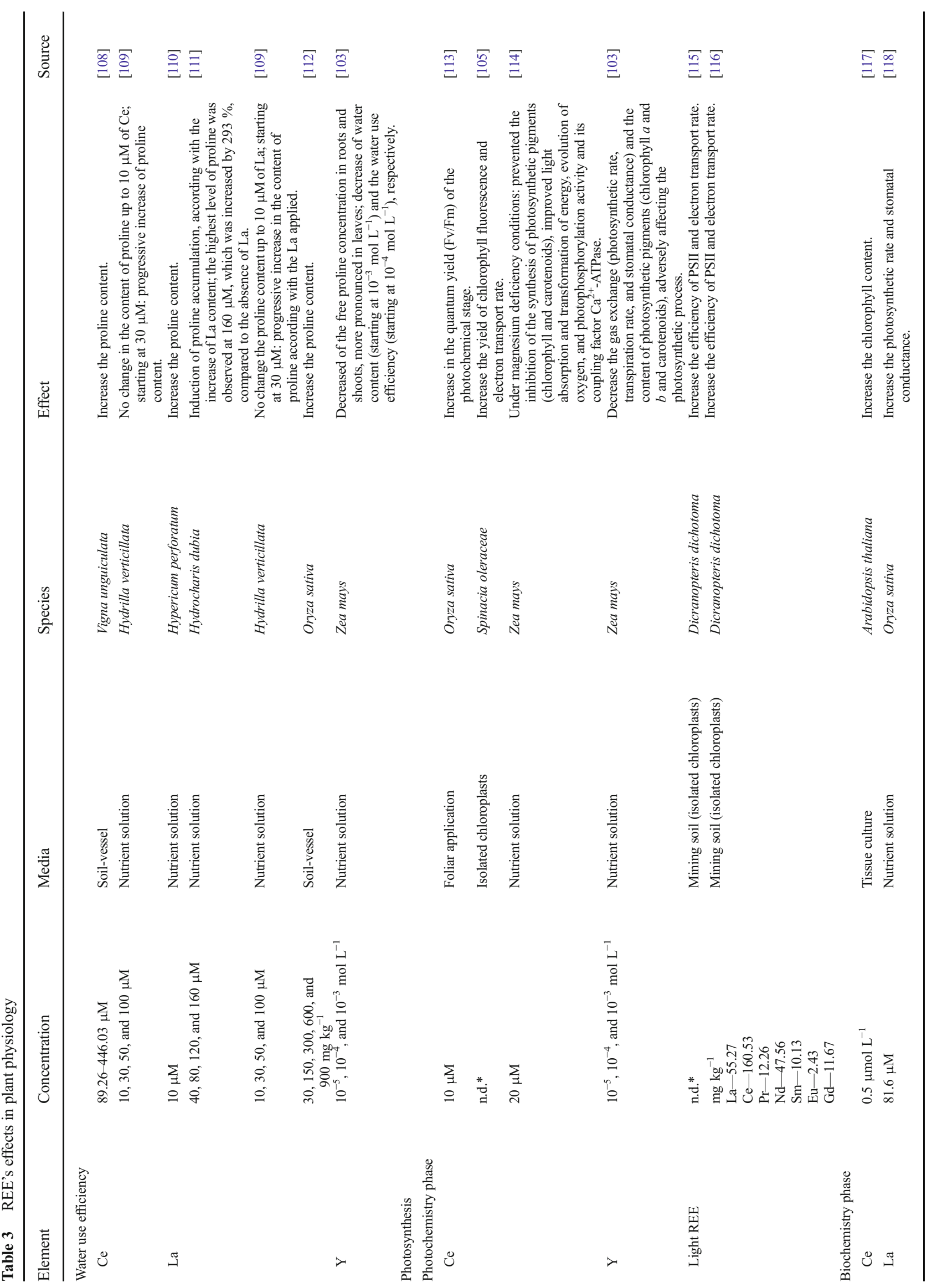




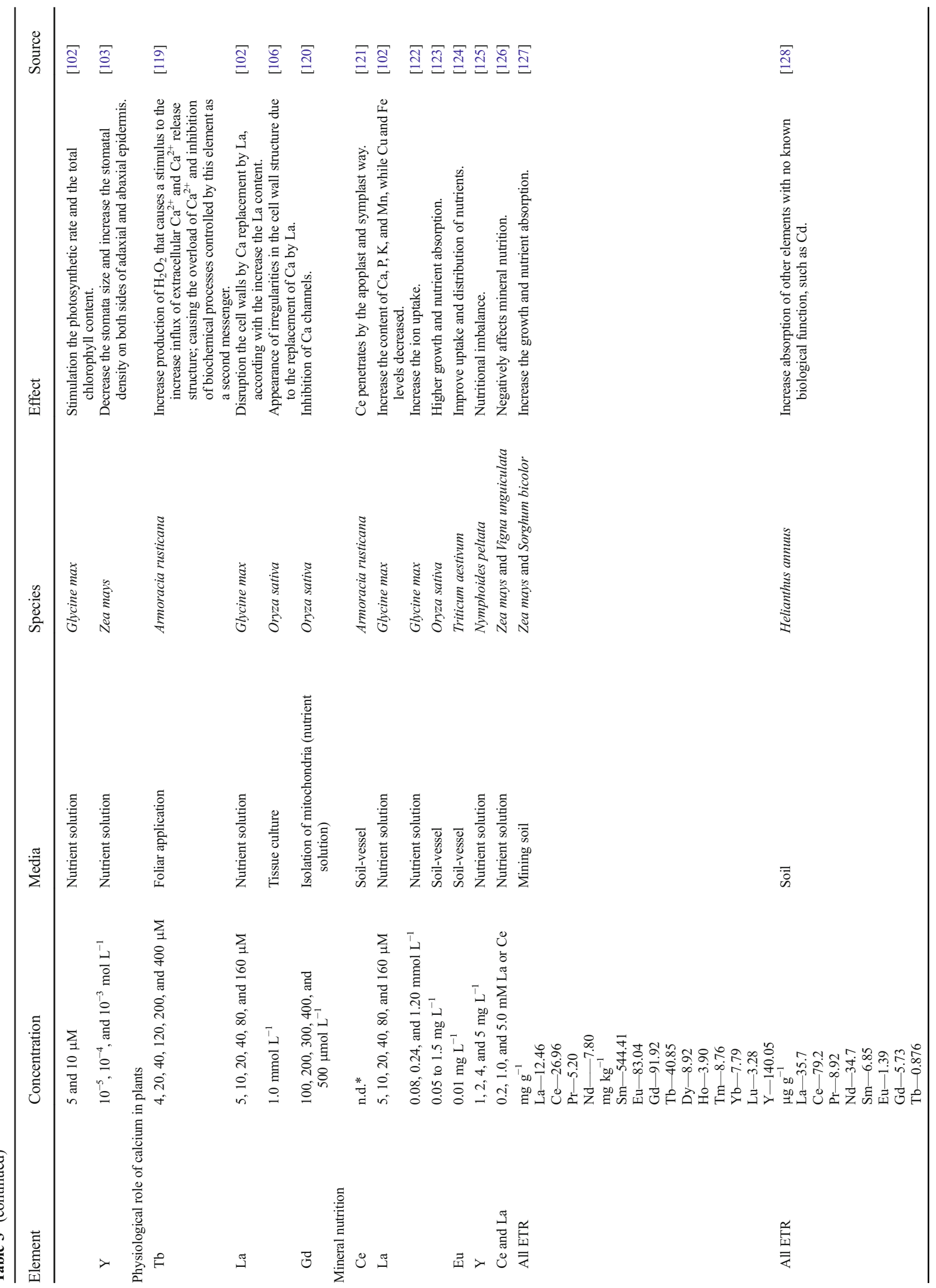




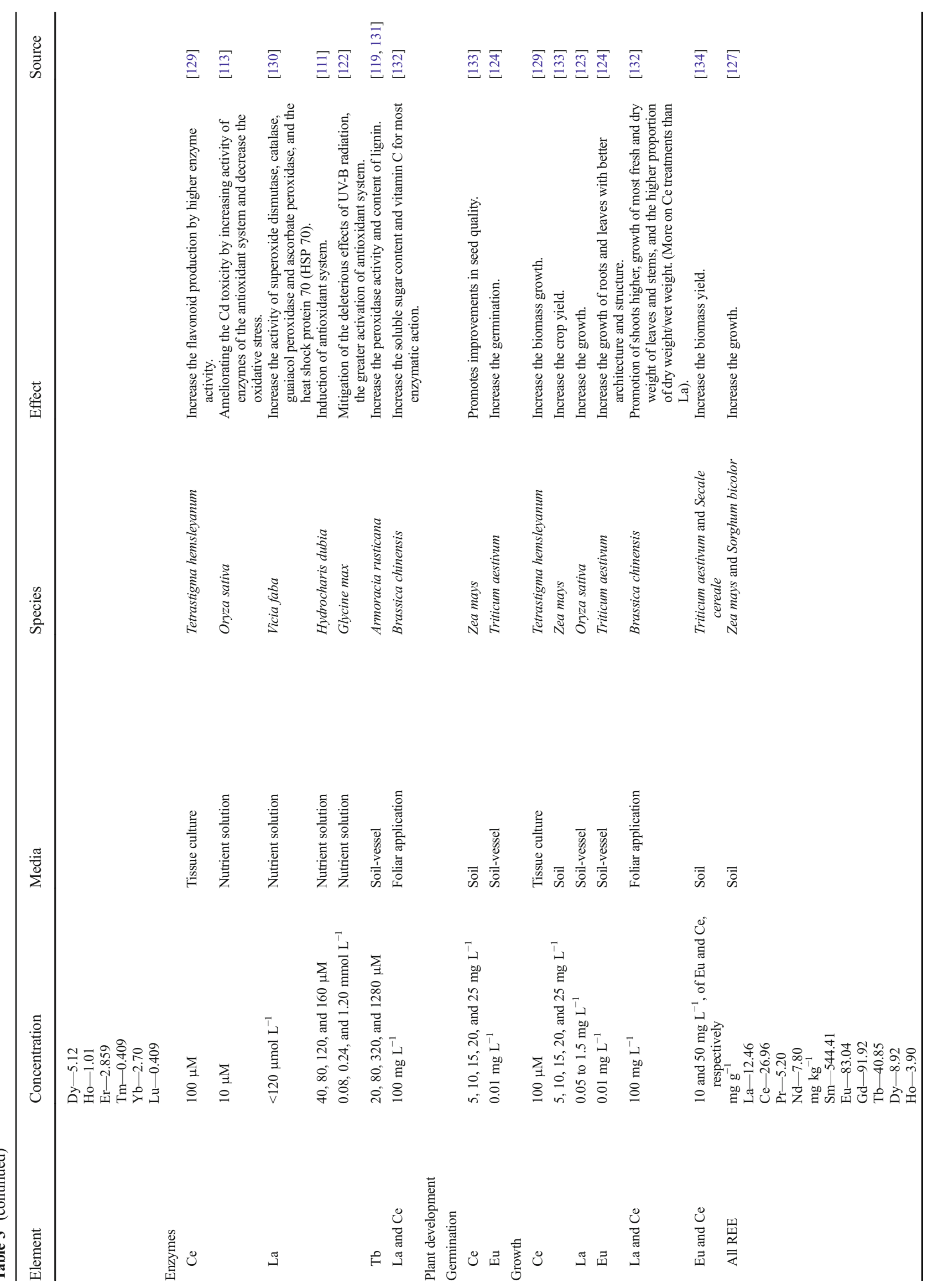




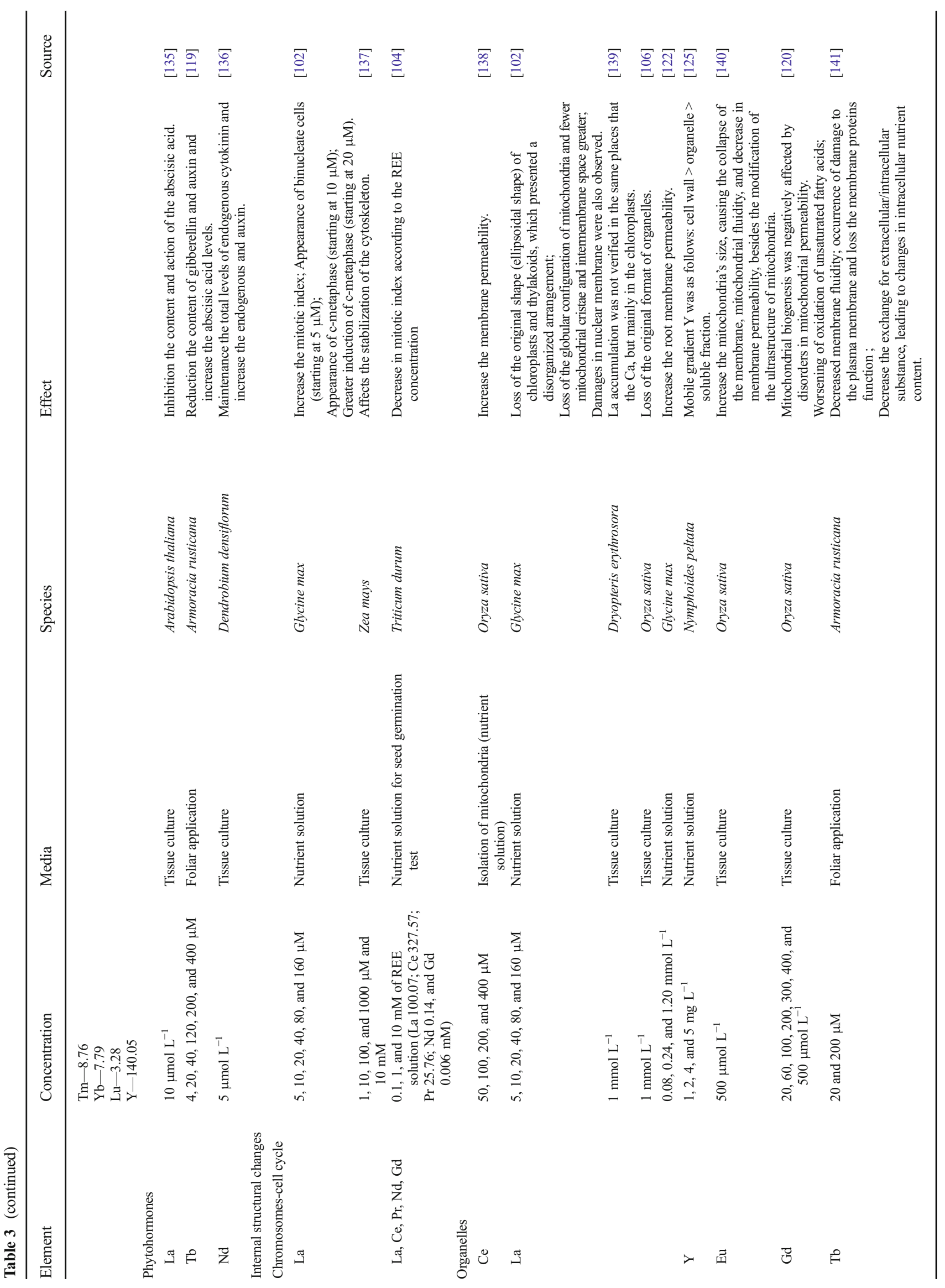


the content of photosynthetic pigments such as chlorophyll, which contributes for a higher photosynthetic rate $[102,114$, 117].

\section{Calcium-Like Physiological Effects}

The REE, La in special, can act as Ca replacements, mainly in plant structure, bonding with cell walls in which Ca would be part of the composition and replacing it in its function as a secondary messenger [106].

Due to the fact that $\mathrm{La}$ and $\mathrm{Ca}$ are chemically and physically similar, the manner that they act is similar in plants, inducing the competition and substitution of Ca by La [20, 149]. This replacement in general promotes structural modifications [106, 120], such as loss of structuring in the medium lamella. La can also replace $\mathrm{Ca}$ in the protoplasm, chloroplasts, mitochondria, and cytoplasmatic membranes [102, 107]. Besides this, La can replace $\mathrm{Ca}$ in $\mathrm{Ca}$ oxalate crystals, which are present in many plant tissues [103]. Similarly to La, other REE have also been associated to this type of $\mathrm{Ca}$ replacement, due to their very similar ionic radius $[118,120]$.

\section{Mineral Plant Nutrition}

The effects of REE in plant mineral nutrition are varied. Some studies report synergism with some elements, while others show antagonism [124, 126, 127, 149, 150]. For some species, the presence of REE can promote beneficial effects on uptake and translocation of nutrients such as nitrogen, thus increasing the production of amino acids and proteins, which will act in several metabolic routes, leveraging plant vital processes [97].

Other nutrients such as $\mathrm{Fe}, \mathrm{Cu}$, and $\mathrm{Mn}$ can also have their absorption increased in the presence of REE, in several species. This can increase the amount of cofactors involved in several metabolic processes and promote an increase in plant growth $[102,127,134,150]$. In addition, there are reports that the presence of REE may lead also to an increased absorption of other elements with no known biological function, such as Cd [128].

\section{Enzymatic System}

The stimulus to enzyme production and activation in plants, due to the presence of REE, is associated with an influx of nutrients that constitute these enzymatic molecules and also to a higher influx of cofactors and catalysts of enzymatic reactions that will trigger their activity $[129,132]$. There are also studies that correlate the presence of REE to a higher activity of the antioxidant enzymatic system [112, 117, 119, 130, 131, $150]$. 


\section{Effects of REE on Plant Development}

\section{Seed Germination}

Some studies report positive effects of REE in seed germination, mainly because these elements act in a synergistic manner with phytohormones that stimulate germination, besides inhibiting phytohormones that negatively affect seed germination, as it will be described further [124, 133].

\section{Plant Growth}

It has been broadly reported that REE positively influence plant growth, increasing biomass production $[127,129,132$, $134,149]$. Other factors related to plant growth that contribute to an increase of productivity, such as better plant structuring and architecture, have been also associated with the presence of REE [124].

\section{Phytohormones}

The production of phytohormones is affected by the presence of REE, and this interaction has been proposed as one of the mechanisms through which these elements can influence plant growth. However, it is not clear yet if REE are directly involved with signalization of plant hormones, and the responses regarding stimulus or inhibition of phytohormones are variable among species and among REE [119]. While a synergism has been reported between the presence of $\mathrm{Tb}$ and the production and action of abscisic acid, the opposite was observed regarding auxin and gibberellin [119]. On the other hand, Nd did not influence total levels of endogenous cytokinin and significantly increased the level of auxin [136].

\section{Effects of REE on Plant Internal Structure}

\section{Chromosomes-Cell Cycle}

It is reported that REE may act as inducers of the cell cycle, increasing or reducing the mitotic index in plants [102, 104]. Besides altering the mitotic index, at low concentration, La was described to promote the appearance of abnormalities in the cell cycle, favoring biomass growth due to the duplication of the cell genome; i.e., the appearance of polyploidized cells (binucleated) resulted in increasing tissue size. Yet, a further increase in La concentration led to the appearance of abnormalities such as c-metaphases, indicating La toxicity [102]. Moreover, there are studies demonstrating that REE may cause destabilization of the cytoskeleton, affecting the cell cycle [137].
Organelles

Since REE can bind to plant structures, they can cause cell destructuring (by Ca replacement). These destructuring processes are commonly verified in cell walls [125, 142] and also occur frequently in chloroplasts, mitochondria, and nuclei that lose their original format $[102,106,140]$. The main reports of REE effects on membrane stability are associated to alterations of stability, functionality, and permeability [120, 138, 140, 150, 151].

Tissues

There are reports that root protecting tissues (cap), which have direct contact with REE present in soil solution, can be increased, as a protection to their excessive influx, which constitutes the mechanism of plant tolerance to these elements. Besides this, other tissues can be thickened, such as apoplastic barriers, to avoid the translocation of these elements to shoots [143]. Additionally, the dimensions and density of structures such as the stomata can be modified as a way to keep the photosynthetic process in the presence of these elements [103].

\section{Ecological and Human Health Risks Associated with REE}

Even though many medical and pharmacological studies have been reported with REE [152-156], so far, little attention has been given to ecological and environmental aspects related to the presence of REE in soils and their possible transference in the trophic chain $[157,158]$.

Several studies involving effects of REE in experimental animals have reported an accumulation of these elements with time. The main spots for accumulation are the bones, liver, and lungs [156, 159, 160]. Some damage can be mentioned, such as cardiac, hepatic, hematological, and renal problems, besides effects in the gastrointestinal tract, in bones, in the central nervous system, and in the pulmonary and cytogenetic systems [79, 156, 159-162]. Despite this, the current information is not enough to determine the safe levels of exposure in humans [160], with values found being described as temporary [163].

In studies that evaluate the risk to human health, the dose representing an estimate, with uncertainty spanning perhaps an order of magnitude, of a daily oral exposure to the human population (including sensitive subgroups) that is likely to be without an appreciable risk of deleterious effects during a lifetime is called oral reference dose (RfD) [160, 161]. Toxicological studies provide a basis for deriving nonobserved adverse effect level (NOAEL) and lowest observed adverse effect level (LOAEL) contents. By applying 
uncertainty and modification factors (specific to each condition), values for RfD are obtained [160, 161]. It is possible to compare the toxicity of different substances through RfD values. These values are used to estimate the risk for a certain group, by comparing the exposure level to the effect level (RfD). Table 4 presents RfD values for some REE. The existence of a distinct toxicity between the elements and for one element alone is emphasized in this table, depending on its accompanying ion.

Even though these data are useful to evaluate potential risks of REE to humans, only in specific cases, there will be direct exposure to salts/oxides of these elements. In most cases, the major exposure routes will be ingestion of food, water, and contaminated soil, as well as dermal contact and inhalation of fumes and particulate materials [163]. Therefore, it is necessary to know the real doses to which the organisms are exposed to.

There are evidences that REE may accumulate in the soil surface due to their sorption onto soil colloids [79, 157], which consequently can lead to low bioavailability. This is directly affected by factors such as $\mathrm{pH}$ and the presence of organic and inorganic ligands [158]. Under these circumstances, if there is ingestion of REE-contaminated soil, the total content of the element possibly would not represent the real risk.

For better risk estimates of soil-derived REE, it would be necessary to perform bioaccessibility studies, such as those implemented by Smith et al. [91], who evaluated bioaccessible contents (physiologically based extraction test) of $\mathrm{La}, \mathrm{Ce}$, and $\mathrm{Nd}$ in soil samples (ground soils) and soils eaten deliberately, such as termite nest soils and traditional herbal-soil remedies, in the district of Mukono (Uganda). The average bioaccessibility varied from 2.9 to $14 \%$ for $\mathrm{La}, 1$ to $15 \%$ for $\mathrm{Ce}$,

Table 4 Provisional reference doses ( $\mathrm{p}-\mathrm{RfD})$ for selected REE.

\begin{tabular}{ll}
\hline Element & $p$-RfD $\left(\mathrm{mg} \mathrm{kg}^{-1} \mathrm{day}^{-1}\right)$ \\
\hline Europium (chloride) & 0.03 \\
Europium (oxide) $^{\mathrm{a}}$ & 0.002 \\
Lanthanum (carbonate) $^{\mathrm{a}}$ & 0.5 \\
Lanthanum (chloride) $_{\text {Lanthanum (oxide) }}$ & 0.005 \\
Lutetium(chloride) & 0.02 \\
Neodymium (chloride) & 0.0009 \\
Praseodymium (chloride) & 0.5 \\
Samarium (chloride) & 0.5 \\
Samarium (nitrate) & 0.5 \\
Scandium (oxide) & 0.00002 \\
Yttrium (chloride) & 0.005 \\
\hline
\end{tabular}

Source: [160-163]

${ }^{\mathrm{a}}$ This value was not considered provisional and 3.4 to $19 \%$ for Nd. A smaller bioaccessibility was observed in soil samples, when compared with the other materials evaluated. The authors concluded that the low bioaccessible levels of Ce considerably reduce the contribution of $\mathrm{Ce}$ exposure values via direct soil ingestion. In addition, the authors suggest that REE bioaccessibility in food is reduced due to the presence of organic complexes, such as phytates. These results are relevant, since bioaccessibility studies performed for other elements show evidences to conclude that an overestimation of risk can occur if the risk evaluation considers only the total contents $[164,165]$. Adding to this, there is also the need for speciation studies, in order to identify the soluble and insoluble species for each soil environment [79, 157].

Thus, additional experiments that seek to evaluate the real contents to which human beings are exposed to REE are an urgent need. These results could possibly reduce the pressures imposed mainly on agriculture, which is the main activity (as a diffuse source) responsible for increasing the contents of REE in soils [53], due to either REE direct (China) or indirect use (other countries). Knowing several bioaccessibility scenarios for these elements would allow decision-making with higher safety.

In the absence of these researches, analyses of "case studies" can allow, in a preliminary manner, to associate exposure conditions to their effects. Table 5 shows some of these studies. It is verified that hair, blood, and urine can be used as exposure indicators. Populations exposed to elevated REE contents can present alterations in these parameters. Table 5 also shows studies that can help to evaluate ecological risks.

Regarding ecological risk evaluations, it cannot be affirmed if there is or there is not risk in a generalized manner. Each scenario must be specifically evaluated, taking the intrinsic variability of each environment into consideration, as well as the evaluation objectives, target organisms, among others [172].

It is known that REE toxicity is variable, depending on toxicological parameters and the target organisms [157]. Besides this, the chemical forms of REE compounds primarily determine deposition and retention of REE following the different routes of exposure [156]. Tables 6 and 7 show $\mathrm{LD}_{50}$ values (lethal dose to $50 \%$ of exposed individuals) for some REE through different administration routes. These data reinforce the need to evaluate bioaccessible contents, particularly when taking into consideration the great differences found between different routes of exposure, e.g., oral versus intravenous.

With the purpose of evaluating ecological risk, part of the information shown in Table 3, which report selected adverse effects of REE in plants (and their respective concentrations), could be used to construct a database that allows the elaboration of mathematical models to estimate safe doses of REE in soils. However, the existence of a limited number of studies in this subject, as well as others 


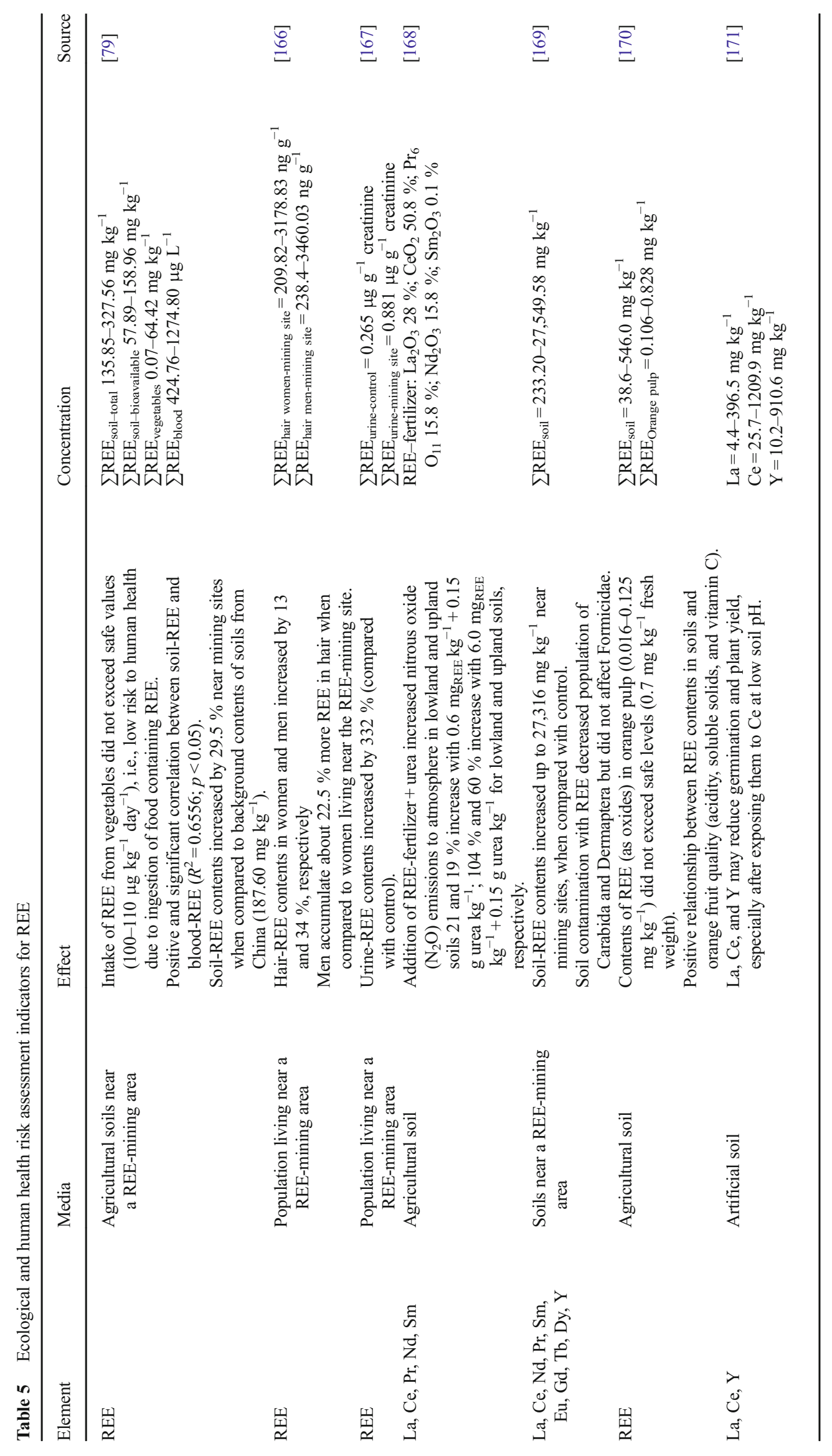


Table 6 Acute intraperitoneal, oral, and intravenous toxicity of rare earth nitrates to female/male mice and rats $\left(\mathrm{LD}_{50}\right)$

\begin{tabular}{|c|c|c|c|c|c|}
\hline \multirow[t]{2}{*}{ REE } & \multicolumn{2}{|l|}{ Intraperitoneal } & \multirow{2}{*}{$\begin{array}{l}\text { Oral } \\
\text { Female rats } \\
\mathrm{mg} \mathrm{kg}^{-1}\end{array}$} & \multicolumn{2}{|l|}{ Intravenous } \\
\hline & $\begin{array}{l}\text { Female mice } \\
\mathrm{mg} \mathrm{kg}^{-1}\end{array}$ & $\begin{array}{l}\text { Female rats } \\
\mathrm{mg} \mathrm{kg}^{-1}\end{array}$ & & $\begin{array}{l}\text { Female rats } \\
\mathrm{mg} \mathrm{kg}^{-1}\end{array}$ & $\begin{array}{l}\text { Male rats } \\
\mathrm{mg} \mathrm{kg}^{-1}\end{array}$ \\
\hline Lanthanum & 131 & - & - & - & - \\
\hline Cerium & 151 & 93 & 1355 & 1.4 & 16 \\
\hline Praseodymium & 94.4 & 79 & 1134 & 2.4 & 25 \\
\hline Neodymium & 89 & 89 & 905 & 2.1 & 22 \\
\hline Samarium & 106 & 96 & 901 & 3 & 20 \\
\hline Europium & 109 & 72 & $>1704$ & - & - \\
\hline Gadolinium & 105 & 80 & $>1743$ & - & - \\
\hline Terbium & 168 & 91 & $>1753$ & - & - \\
\hline Dysprosium & 110 & 105 & 1103 & - & - \\
\hline Holmium & 115 & 97 & 1078 & - & - \\
\hline Erbium & 81 & 83 & - & 13 & 19 \\
\hline Thulium & 93 & 104 & - & - & - \\
\hline Ytterbium & 93 & 94 & 1148 & - & - \\
\hline Lutetium & 108 & 125 & - & - & - \\
\hline
\end{tabular}

Source: [154]

involving several important ecological indicators (e.g., invertebrates, birds, etc.), reveals the big challenge that researchers still have in generating consistent information in order to evaluate the real effects of REE present in soils, over the most diverse target organisms that exist in the ecosystems.

Finally, it is worth mentioning that even though studies that evaluate REE effects in the environment can present relevant information in order to contribute to ecological risk evaluation, the comparison of existing studies is difficult due to methodological divergences [157]. Moreover, existing divergences between beneficial and adverse results can also be related to the doses used, which are not broad enough to overcome the controversy associated with the hormesis phenomenon [158].

Table 7 Acute intraperitoneal and oral toxicity of rare earth chlorides to male mice $\left.\left(\mathrm{LD}_{50}\right)\right]$

\begin{tabular}{lll}
\hline REE & $\begin{array}{l}\text { Intraperitoneal } \\
\mathrm{mg} \mathrm{kg}^{-1}\end{array}$ & $\begin{array}{l}\text { Oral } \\
\mathrm{mg} \mathrm{kg}^{-1}\end{array}$ \\
\hline Dysprosium & 585 & 7650 \\
Erbium & 535 & 6200 \\
Gadolinium & 550 & $>2000$ \\
Holmium & 560 & 7200 \\
Samarium $^{\text {Scandium }}{ }^{\mathrm{a}}$ & 585 & $>2000$ \\
Terbium $^{\text {Thulium }}$ & 440 & - \\
Dysprosium & 550 & 5100 \\
\hline
\end{tabular}

Source: [155, 156, 173-175]

${ }^{\mathrm{a}}$ Intravenous $=24 \mathrm{mg} \mathrm{kg}^{-1}$

\section{Conclusion}

Current uses of rare earth elements (REE) include automobile catalysts and petroleum refining, flat panel displays (cell phones, portable DVDs, TVs, and laptops), permanent magnets and rechargeable batteries for hybrid and electric vehicles, numerous medical devices, and in agriculture. Soil is a primary destination of most products/by-products containing REE; however, little is still known about the effects of REE in the soil environment, including effects on plants, animals, and humans. Indeed, despite the increasing number of studies with reference to REE in soils observed in the last 5-6 years, researchers worldwide are still trying to unveil the toxicological effects, as well as the possible benefits of REE to plants. Many questions about the biological role of REE remain unanswered. Even more uncertain and unexplored are models available for ecological and human health risk assessments. It is therefore important that we continue to advance with studies to better understand the effect of native/anthropogenic soil REE contents upon living systems, with special emphasis on cellular functions, nutrient uptake, and bioaccessibility. Increasing information on reference values for REE in soils worldwide has been available recently, yet their chemical behavior, speciation, and availability in the environment are not well known. Finally, studies concerning the use of REE in agriculture in order to increase crop yields should be further refined to understand the actual mechanism of action of these elements on cellular and physiological processes. 
Acknowledgments This review was made possible due to funding provided for the activities of ITV-UFLA Grant No. 020/2012 and CNPq Grant No. 406806/2013-6. The authors are grateful to ITV-Vale, CNPq, CAPES, and FAPEMIG for financial support and scholarships.

\section{Compliance with Ethical Standards}

Conflict of Interest On behalf of all authors, the corresponding author states that there is no conflict of interest.

\section{References}

1. IUPAC. Nomenclature of inorganic chemistry. Recommendations 2005. Connelly NG et al., editors. 2005.

2. Smuc NR et al. Geochemical characteristics of rare earth elements (REEs) in the paddy soil and rice (Oryza sativa L.) system of Kočani Field, Republic of Macedonia. Geoderma. 2012;183184:1-11.

3. Robinson WO et al. Biogeochemistry of the rare earth elements with particular reference to hickory trees. Geochim Cosmochim Acta. 1958;14:55-67.

4. Skovran E, Martinez-Gomez NC. Just add lanthanides. Science. 2015;348:862-3.

5. Thyssen P, Binnemans K. Accommodation of rare earths in the periodic table: a historical analysis. In: Jr. KAG et al., editors. Handb. Phys. Chem. Rare Earths. 41st ed. 2011.

6. Hurst CA. China's ace in the hole. U.S. Geological Survey National Minerals Information Center. Jt Force Q. 2010;59:1216.

7. Migaszewski ZM, Gałuszka A. The characteristics, occurrence, and geochemical behavior of rare earth elements in the environment: a review. Crit Rev Environ Sci Technol. 2014;45:429-71.

8. Tyler G. Rare earth elements in soil and plant systems - a review. Plant Soil. 2004;267:191-206.

9. Kabata-Pendias A. Trace elements in soils and plants. 2011.

10. Pang $\mathrm{X}$ et al. Application of rare-earth elements in the agriculture of China and its environmental behavior in soil. Environ Sci Pollut Res Int. 2002;9:143-8.

11. Chen Z. Global rare earth resources and scenarios of future rare earth industry. J Rare Earths. 2011;29:1-6.

12. USGS. U.S. Geological Survey. Mineral commodity summaries 2015: U.S. Geological Survey. Reston. 2015.

13. Dołegowska S, Migaszewski ZM. Anomalous concentrations of rare earth elements in the moss-soil system from south-central Poland. Environ Pollut. 2013;178:33-40.

14. Jorjani E, Shahbazi M. The production of rare earth elements group via tributyl phosphate extraction and precipitation stripping using oxalic acid. Arab J Chem King Saud University. 2012;2: 433-598.

15. Alonso E et al. Evaluating rare earth element availability: a case with revolutionary demand from clean technologies. Environ Sci Technol. 2012;46:3406-14.

16. Chakhmouradian AR, Wall F. Rare earth elements: minerals, mines, magnets (and more). Elements. 2012;8:333-40.

17. Massari S, Ruberti M. Rare earth elements as critical raw materials: focus on international markets and future strategies. Resour Policy. 2013;38:36-43.

18. Zhu MY et al. A review of REE tracer method used in soil erosion studies. Agri. Sci. China. Chinese Academy of Agricultural Sciences. 2010;9:1167-1174.

19. Wang $L$ et al. An experimental study on using rare earth elements to trace phosphorous losses from nonpoint sources. Chemosphere. 2011;85:1075-9.
20. $\mathrm{Hu} \mathrm{Z}$ et al. Physiological and biochemical effects of rare earth elements on plants and their agricultural significance: a review. J Plant Nutr. 2004;27:183-220.

21. Nikanorov AM. The Oddo-Harkins rule and distribution of chemical elements in freshwater ecosystems. Dokl Earth Sci. 2009;426: 600-4.

22. Pourmand A et al. A novel extraction chromatography and MCICP-MS technique for rapid analysis of REE, Sc and Y: revising CI-chondrite and post-Archean Australian shale (PAAS) abundances. Chem Geol. 2012;291:38-54.

23. Haskin LA, Frey FA. Meteoritic, solar and terrestrial rare-earth distributions. Phys Chem Earth. 1966;7:167-321.

24. Teixeira, W et al. Decifrando a Terra. $1^{\text {a }}$ Edição.São Paulo: Editora Nacional. 2000.

25. Taylor SR, Mclennan SM. The geochemical the continental evolution crust. Am Geophys Union. 1995;241-265.

26. Gromet LP et al. The "North American shale composite"-its compilation, major and trace element characteristics. 1984;48: 2469-2482.

27. McLennan SM. Rare earth elements in sedimentary rocks; influence of provenance and sedimentary processes. Rev in Mineralogy Geochemistry. 1989;21:169-200.

28. Jordens A et al. A review of the beneficiation of rare earth element bearing minerals. Miner Eng. 2013;41:97-114.

29. Gupta C, Krishnamurthy N. Extractive metallurgy of rare earths Florifa: CRC Press; 2005.

30. Kanazawa Y, Kamitani M. Rare earth minerals and resources in the world. J Alloys Compd Lausanne. 2006;408-412:1339-43.

31. Sha LK, Chappell BW. Apatite chemical composition, determined by electron microprobe and laser-ablation inductively coupled plasma mass spectrometry, as a probe into granite petrogenesis. Geochim Cosmochim Acta. 1999;63:3861-81.

32. Pendias AK, Mukherjee AB. Trace elements of group 3 (Previously Group IIIb). Trace Elem. from Soil to Human. 2007. pp. 127-150.

33. Vijayan $\mathrm{S}$ et al. Rare earths: their mining, processing, and growing industrial usage. Min Eng. 1989;41:13-8.

34. Kynicky J et al. Diversity of rare earth deposits: the key example of China. Elements. 2012;8:361-7.

35. Picard S et al. Rare earth element contents of Jurassic fish and reptile teeth and their potential relation to seawater composition (Anglo-Paris Basin, France and England). Chem Geol. 2002;186: $1-16$.

36. Taunton AE et al. Geomicrobiological controls on light rare earth element, $\mathrm{Y}$ and $\mathrm{Ba}$ distributions during granite weathering and soil formation. J Alloys Compd. 2000;303-304:30-6.

37. Condie $\mathrm{KC}$ et al. Behavior of rare earth elements in a paleoweathering profile on granodiorite in the Front Range, Colorado. USA Geochim Cosmochim Acta. 1995;59:279-94.

38. Grandjean-Lécuyer $P$ et al. Rare earth elements in old biogenic apatites. Geochim Cosmochim Acta. 1993;57:2507-14.

39. Yunxiang Ni JMH, Mariano AN. Crystal chemistry of the monazite and xenotime structures. Am Mineral. 1995;80:21-6.

40. Zhang FS et al. Rare earth element content in various waste ashes and the potential risk to Japanese soils. Environ Int. 2001;27:3938

41. $\mathrm{Hu} \mathrm{Z}$ et al. Rare earth elements in soils. Commun Soil Sci Plant Anal. 2006;37:1381-420.

42. Cidu R et al. Dynamics of rare earth elements in water-soil systems: the case study of the Pineta San Vitale (Ravenna, Italy). Geoderma. 2013;193-194:52-67.

43. Price DG. Weathering and weathering processes. Quarterly J Eng Geol. 1995;28:243-52.

44. Gnandi K, Tobschall HJ. Distribution patterns of rare-earth elements and uranium in tertiary sedimentary phosphorites of Hahotoé-Kpogamé. Togo J African Earth Sci. 2003;37:1-10. 
45. El-Ramady HRH. Ecotoxicology of rare earth elements: ecotoxicology of rare earth elements within soil and plant environments. KG: VDM Verlag Dr. Muller Aktiengsellsellshaft \& Co; 2010.

46. Lijun $\mathrm{W}$ et al. Biogeochemical cycle and residue of extraneous rare earth elements in agricultural ecosystem. J Rare Earths. 2004;22:701-6.

47. Smidt GA et al. Heavy metal concentrations in soils in the vicinity of a fertilizer factory in Southern Brazil. Agriculture and Forestry Research. 2011;61:353-64.

48. Xie $\mathrm{Y}$ et al. REE geochemistry of modern eolian dust deposits in Harbin city, Heilongjiang province. China: Implications for provenance Catena. 2014;123:70-8.

49. Waheed $\mathrm{S}$ et al. Rare earths elements in phosphorite and granulated single super-phosphate fertilizers of Pakistan, a study using instrumental neutron activation analysis. J Radioanal Nucl Chem. 2011;289:521-8.

50. Abdel-Haleem AS et al. Heavy metals and rare earth elements in phosphate fertilizer components using instrumental neutron activation analysis. Appl Radiat Isot. 2001;55:569-73.

51. Todorovsky DS et al. Effect of the application of superphosphate on rare earths' content in the soil. Sci Total Environ. 1997;203:136.

52. Otero $\mathrm{N}$ et al. Fertiliser characterisation: major, trace and rare earth elements. Appl Geochemistry. 2005;20:1473-88.

53. Turra $\mathrm{C}$ et al. Evaluation on rare earth elements of Brazilian agricultural supplies. J Environ Chem Ecotoxicol. 2011;3:86-92.

54. Al-Thyabat S, Zhang P. REE extraction from phosphoric acid, phosphoric acid sludge, and phosphogypsum. Miner. Process. Extr. Metall. 2015;0: 1-8.

55. Leonardo L et al. Lichen specie Canoparmelia texana as bioindicator of environmental impact from the phosphate fertilizer industry of São Paulo. Brazil J Radioanal Nucl Chem. 2014;299: 1935-41.

56. Dinali GS. Elementos terras raras em materiais derivados da indústria de fosfatos. Universidade Federeal de Lavras. 2014.

57. $\mathrm{Xu} \mathrm{X}$ et al. Distributions of rare earths and heavy metals in fieldgrown maize after application of rare earth-containing fertilizer. Sci Total Environ. 2002;293:97-105.

58. Jones DL. Trivalent metal $(\mathrm{Cr}, \mathrm{Y}, \mathrm{Rh}, \mathrm{La}, \mathrm{Pr}, \mathrm{Gd})$ sorption in two acid soils and its consequences for bioremediation. Eur J Soil Sci. 1997;697-702.

59. Cao X et al. Effects of redox potential and $\mathrm{pH}$ value on the release of rare earth elements from soil. Chemosphere. 2001;44:655-61.

60. Fendorf S, Fendorf M. Sorption mechanism of lanthanum on oxide minerals. Clay Clays Miner. 1996;44:220-7.

61. Bao Z, Zhao Z. Geochemistry of mineralization with exchangeable REY in the weathering crusts of granitic rocks in South China. Ore Geol Rev. 2008;33:519-35.

62. Caspari $\mathrm{T}$ et al. Geochemical investigation of soils developed in different lithologies in Bhutan. Eastern Himalayas Geoderma. 2006; 136:436-58.

63. Ayres M, Harris N. REE fractionation and Nd-isotope disequilibrium during crustal anatexis: constraints from Himalayan leucogranites. Chem Geol. 1997;139:249-69.

64. Beckwith R, Butler J. Aspect of the chemistry of soil organic matter. Soil, an Australian viewpoint. Vic CSIRO/Academic Press. 1993. pp. 561-581.

65. Xiangke $\mathrm{W}$ et al. Sorption and desorption of Eu and $\mathrm{Yb}$ on alumina: mechanisms and effect of fulvic acid. Appl Radiat Isot. 2000;52:165-73.

66. Pourret $\mathrm{O}$ et al. Organic complexation of rare earth elements in natural waters: evaluating model calculations from ultrafiltration data. Geochim Cosmochim Acta. 2007;71:2718-35.

67. Tang J, Johannesson KH. Rare earth elements adsorption onto Carrizo sand: influence of strong solution complexation. Chem Geol. 2010;279:120-33.
68. Zhu QQ, Liu Z. REEs in soil of eastern China. J Chinese Rare Earth Soc. 1988;6:59-65.

69. Kawasaki A et al. Rare earth elements and other trace elements in wastewater treatment sludges. Soil Sci Plant Nutr. 2012;44:43341.

70. Zhang S, Shan XQ. Speciation of rare earth elements in soil and accumulation by wheat with rare earth fertilizer application. Environ Pollut. 2001;112:395-405.

71. Salminen RB et al. FOREGS Geochimical Atlas of Europe, part 1: background information, methodology and maps. Geol. Surv. Finland, Espoo. 2005.

72. Markert B. The pattern of distribution of lanthanide elements in soils and plants. Phytochemistry. 1987;26:3167-170.

73. Loell $\mathrm{M}$ et al. Contents and bioavailability of rare earth elements in agricultural soils in Hesse (Germany). J Plant Nutr Soil Sci. 2011;174:644-54.

74. Markert B, Li ZD. Natural background concentrations of rareearth elements in a forest ecosystem. Sci Total Environ. 1991;103:27-35.

75. Diatloff $\mathrm{E}$ et al. Concentrations of rare earth elements in some Australian soils. Aust J Soil Res. 1996;34:735.

76. Moreira CG. Elementos terras raras em solos agrícolas com aplicações de fertilizante fosfatado e fosfogesso. 2014.

77. Oliveira KAP et al. Transfer factor of rare earth elements from phosphogypsum amended Brazilian tropical soils to lettuce, corn and soybean. J Solid Waste Technol Manag. 2012;38:202-10.

78. Marques R et al. REE and other trace and major elements in the topsoil layer of Santiago island. Cape Verde J African Earth Sci. 2012;64:20-33.

79. $\mathrm{Li} \mathrm{X}$ et al. A human health risk assessment of rare earth elements in soil and vegetables from a mining area in Fujian Province. Southeast China Chemosphere. 2013;93:1240-6.

80. Miao L et al. Geochemistry and biogeochemistry of rare earth elements in a surface environment (soil and plant) in South China. Environ Geol. 2008;56:225-35.

81. Cheng $\mathrm{H}$ et al. Vertical distribution of rare earth elements in a wetland soil core from the Sanjiang Plain in China. J. Rare Earths. The Chinese Society of Rare Earths. 2012;30:731-8.

82. Zhang $\mathrm{Q}$ et al. Estimation of the detachment rate in eroding rills in flume experiments using an REE tracing method. Geoderma. 2008;147:8-15.

83. Laul JC et al. Biogeochemical distribution of rare earths and other trace elements in plants and soils. Phys Chem Earth. 1979;11:819 27.

84. Takeda A et al. Analysis of 57 elements in Japanese soils, with special reference to soil group and agricultural use. Geoderma. 2004;119:291-307.

85. Yoshida $\mathrm{S}$ et al. Concentrations of lanthanide elements, Th, and $\mathrm{U}$ in 77 Japanese surface soils. Environ Int. 1998;24:275-86.

86. Uchida S et al. Soil-to-plant transfer factors of stable elements and naturally occurring radionuclides (1) upland field crops collected in Japan. J Nucl Sci Technol. 2007;44:628-40.

87. Chojnicki ZEF et al. Rare earth elements in alluvial soils. Rocz Glebozn Tom. 2000;57-65.

88. Sadeghi $\mathrm{M}$ et al. Rare earth element distribution and mineralization in Sweden: an application of principal component analysis to FOREGS soil geochemistry. J Geochemical Explor. 2013;133: 160-75.

89. Öhlander B et al. Mobility of rare earth elements during weathering of till in northern Sweden. Appl Geochemistry. 1996;11:93-9.

90. Tyler G, Olsson T. Conditions related to solubility of rare and minor elements in forest soils. J Plant Nutr Soil Sci. 2002;165: 594-601. 
91. Smith B et al. The bioaccessibility of essential and potentially toxic trace elements in tropical soils from Mukono District. Uganda J Geol Soc. 2000;157:885-91.

92. Saha A et al. Determination of trace rare earth elements in gadolinium aluminate by inductively coupled plasma time of flight mass spectrometry. Spectrochim Acta Part B At Spectrosc. 2014;94-95:14-21.

93. Spalla $\mathrm{S}$ et al. Determination of rare earth elements in tomato plants by inductively coupled plasma mass spectrometry techniques. Rapid Commun Mass Spectrom. 2009;23:3285-92.

94. Tanase IG et al. Validation and quality control of an ICP-MS method for the quantification and discrimination of trace metals and application in paper analysis: an overview. Crit Rev Anal Chem. 2014;44:311-27.

95. Kawabe I et al. Comparison of REE analyses of GSJ carbonate reference rocks by ICP-AES and INAA: fission and spectral interferences in INAA determination of REE in geochemical samples with high U/REE ratios. Geochem J. 1994;28:19-29.

96. Alnour IA et al. Rare earth elements determination and distribution patterns in granite rock samples by using INAA absolute method. J Radioanal Nucl Chem. 2015;303:1999-2009.

97. Redling K. Rare earth elements in agriculture. Universitat Munchen; 2006.

98. Volokh AA et al. Phosphorus fertilizer production as a source of rare-earth elements pollution of the environment. Sci Total Environ. 1990;95:141-8.

99. Chahi A et al. Rare-earth elements as tracers of the genetic relationship between smectite and palygorskite in marine phosphorites. Clay Miner. 1999;34:419.

100. Xiong BK. Application of rare earths in Chinese agriculture and their perspectives of development. In: Rare earths in agricultural sciences, Australian Academy of Technology and Engineering, Carlon South. 1995. pp. 3-9.

101. Guo BS. The application of rare earth elements on agriculture and breeding. Chinese Rare Earths. 1993;34-43.

102. Oliveira $\mathrm{C}$ et al. Bioaccumulation and effects of lanthanum on growth and mitotic index in soybean plants. Ecotox Environ Safe. 2015;122:136-144.

103. Maksimovic I et al. Effect of yttrium on photosynthesis and water relations in young maize plants. J Rare Earths. 2014;32:371-8.

104. d'Aquino $\mathrm{L}$ et al. Effect of some light rare earth elements on seed germination, seedling growth and antioxidant metabolism in Triticum durum. Chemosphere. 2009;75:900-5.

105. Giraldo JP et al. Plant nanobionics approach to augment photosynthesis and biochemical sensing. Nat Mater. 2014;13:400-8

106. Liu D et al. Effects of lanthanum on growth and accumulation in roots of rice seedlings. Plant Soil Environ. 2013;59:196-200.

107. Faheed $\mathrm{F}$ et al. Physiological and ultrastructural studies on calcium oxalate crystal formation in some plants. 2013;139-152.

108. Shyam R, Aery N. Effect of cerium on growth, dry matter production, biochemical constituents and enzymatic activities of cowpea plants [Vigna unguiculata (L.) Walp.]. J. soil Sci. plant Nutr. 2012;12:1-14.

109. Wang $X$ et al. Lanthanum- and cerium-induced oxidative stress in submerged Hydrilla verticillata plants. Russ J Plant Physiol. 2007;54:693-7.

110. Babula $\mathrm{P}$ et al. Lanthanum rather than cadmium induces oxidative stress and metabolite changes in Hypericum perforatum. J Hazard Mater. 2015;286:334-42.

111. Xu Q et al. Laboratory assessment of uptake and toxicity of lanthanum (La) in the leaves of Hydrocharis dubia (Bl.) Backer. Environ Sci Pollut Res. 2012;19:3950-8.

112. Zeng Q et al. Phytotoxicity of lanthanum in rice in haplic acrisols and cambisols. Ecotoxicol Environ Saf. 2006;64:226-33.

113. Wu $\mathrm{M}$ et al. Alleviation of cadmium toxicity by cerium in rice seedlings is related to improved photosynthesis, elevated antioxidant enzymes and decreased oxidative stress. Plant Growth Regul. 2014;74:251-60.

114. Zhou M et al. Improvement of cerium of photosynthesis functions of maize under magnesium deficiency. Biol Trace Elem Res. 2011;142:760-72.

115. Wang L-F. Photosystem 2 photochemistry and pigment composition of Dicranopteris dichotoma Bernh under different irradiances. African J Biotechnol. 2011;10:13453-60.

116. Wang LF et al. Photosystem 2 activities of hyper-accumulator Dicranopteris dichotoma Bernh from a light rare earth elements mine. Photosynthetica. 2006;44:202-7.

117. Wang $\mathrm{X}$ et al. Cerium toxicity, uptake and translocation in Arabidopsis thaliana seedlings. J Rare Earths The Chinese Society of Rare Earths. 2012;30:579-85.

118. Wang $\mathrm{L}$ et al. Combined effects of lanthanum (III) chloride and acid rain on photosynthetic parameters in rice. Chemosphere. 2014; 112:355-61.

119. Wang $\mathrm{L}$ et al. Effects of terbium (III) on signaling molecules in horseradish. Biol. Trace Elem. Res. 2014;122-129.

120. Zhao $J$ et al. High concentration of gadolinium ion modifying isolated rice mitochondrial biogenesis. Biol Trace Elem Res. 2013;156:308-15.

121. Guo X et al. Distribution and translocation of $141 \mathrm{Ce}$ (III) in horseradish. Ann Bot. 2007;100:1459-65.

122. Huang $\mathrm{G}$ et al. Combined effects of lanthanum(III) and elevated ultraviolet-b radiation on root nitrogen nutrient in soybean seedlings. Biol Trace Elem Res. 2014;163:224-34.

123. $\mathrm{Hu} \mathrm{X}$ et al. Bioaccumulation of lanthanum and cerium and their effects on the growth of wheat (Triticum aestivum L.) seedlings. Chemosphere. 2002;48:621-9.

124. Shtangeeva I, Ayrault S. Effects of Eu and Ca on yield and mineral nutrition of wheat (Triticum aestivum) seedlings. Environ Exp Bot. 2007;59:49-58.

125. Fu Y et al. Bioaccumulation, subcellular, and molecular localization and damage to physiology and ultrastructure in Nymphoides peltata (Gmel.) O. Kuntze exposed to yttrium. Environ. Sci. Pollut. Res. 2014;21:2935-2942.

126. Diatloff $\mathrm{E}$ et al. Effects of lanthanum and cerium on the growth and mineral nutrition of corn and mungbean. Ann Bot. 2008;101: 971-82.

127. Guo W et al. Effects of arbuscular mycorrhizal fungi on maize (Zea mays L.) and sorghum (Sorghum bicolor L. Moench) grown in rare earth elements of mine tailings. Appl. Soil Ecol. 2013;72: 85-92.

128. Kötschau A et al. Sunflower (Helianthus annuus): phytoextraction capacity for heavy metals on a mining-influenced area in Thuringia, Germany. Environ. Earth Sci. 2014;2023-2031.

129. Peng X, He JY. The inhibitory effect of $\mathrm{Ca}^{2+}$ on the flavonoid production of Tetrastigma hemsleyanum suspension cells induced by metal elicitors. Vitr Cell Dev Biol Plant. 2013;49:550-9.

130. Wang CR et al. Antioxidant and prooxidant effects of lanthanum ions on Vicia faba L. seedlings under cadmium stress, suggesting ecological risk. Environ. Toxicol. Chem. 2012;31:1355-62.

131. Zhang $\mathrm{X}$ et al. Roles of horseradish peroxidase in response to terbium stress. Biol Trace Elem Res. 2014;161:130-5.

132. Ma JJ et al. Effects of spray application of lanthanum and cerium on yield and quality of Chinese cabbage (Brassica chinensis L) based on different seasons. Biol Trace Elem Res. 2014;160:42732.

133. Espindola MCG et al. Efeito do cério na qualidade fisiológica de sementes de milho e no desempenho agronômico das plantas. Biosci J. 2013;29:1501-7.

134. Shtangeeva I. Europium and cerium accumulation in wheat and rye seedlings. Water Air Soil Pollut. 2014;225:1964-73.

135. Wang $J$ et al. Effects of lanthanum on abscisic acid regulation of root growth in Arabidopsis. J Rare Earths. 2014;32:78-82. 
136. Luo $\mathrm{J}$ et al. Changes in endogenous hormone levels and redox status during enhanced adventitious rooting by rare earth element neodymium of Dendrobium densiflorum shoot cuttings. J Rare Earths. 2008;26:869-74.

137. Liu M, Hasenstein KH. $\mathrm{La}^{3+}$ uptake and its effect on the cytoskeleton in root protoplasts of Zea mays L. Planta. 2005;220:658-66.

138. $\mathrm{Xia} \mathrm{CF}$ et al. $\mathrm{Ce}(\mathrm{III})$-Induced rice mitochondrial permeability transition investigated by spectroscopic and microscopic studies. Biol Trace Elem Res. 2013;152:284-91.

139. Ozaki Tet al. Beneficial effect of rare earth elements on the growth of Dryopteris erythrosora. J Plant Physiol. 2000;156:330-4.

140. Gao J et al. Membrane permeability transition and dysfunction of rice mitochondria effected by Er(III). J Membr Biol. 2014;248:39 46.

141. Yang Q et al. Toxic effects of heavy metal terbium ion on the composition and functions of cell membrane in horseradish roots. Ecotox Environ Safe. 2015;111:48-58.

142. Shen $\mathrm{Y}$ et al. Eucalyptus tolerance mechanisms to lanthanum and cerium: subcellular distribution, antioxidant system and thiol pools. Chemosphere. 2014;117:567-74.

143. Duarte ACO Efeito de elementos terras raras nas características anatômicas, fisiológicas e nutricionais de Pistia stratiotes L . (Araceae) e Zea mays L . (Poaceae). Universidade Federal de Lavras; 2015.

144. Turra C et al. Rare earth elements in citrus production systems. J Plant Nutr. 2013;36:762-71.

145. Brioschi $L$ et al. Transfer of rare earth elements (REE) from natural soil to plant systems: implications for the environmental availability of anthropogenic REE. Plant Soil. 2013;366:143-63.

146. Gao Y et al. Research of the entry of rare earth elements $\mathrm{Eu}^{3+}$ and $\mathrm{La}^{3+}$ into plant cell. Biol Trace Elem Res. 2003;91:253-65.

147. $\mathrm{Xu} \mathrm{X}$ et al. Accumulation of rare earth elements in maize plants (Zea mays L.) after application of mixtures of rare earth elements and lanthanum. Plant Soil. 2003;252:267-77.

148. Liu D et al. The effects of cerium on the growth and some antioxidant metabolisms in rice seedlings. Environ Sci Pollut Res. 2012;19:3282-91.

149. Xie ZB et al. Effect of lanthanum on rice production, nutrient uptake, and distribution. J Plant Nutr. 2002;25:2315-31.

150. Huang GR et al. Combined effects of lanthanum(III) and elevated ultraviolet-B radiation on root growth and ion absorption in soybean seedlings. Environ Sci Pollut Res. 2014;21:3621-33.

151. Wang $\mathrm{L}$ et al. Toxic effect of heavy metal terbium ion on cell membrane in horseradish. Chemosphere. 2010;80:28-34.

152. Haley TJ et al. Pharmacology and toxicology of dysprosium, holmium, and erbium chlorides. Toxicol Appl Pharmacol. 1966;3743.

153. Haley TJ et al. Toxicological and pharmacological effects of gadolinium and samarium chlorides.pdf. Brit. J. Pharmacol. 1961;526-532.

154. Bruce DW et al. The acute mammalian toxicity of rare earth nitrates and oxides. Toxicol Appl Pharmacol. 1963;5:750-9.

155. Lachine EE et al. Toxicity, tissue distribution and excretion of ${ }^{46} \mathrm{ScCl}_{3}$ and ${ }^{46} \mathrm{Sc}-\mathrm{EDTA}$ in mice. Int $\mathrm{J}$ Appl Radiat Isot. 1976;27:373-7.

156. Hirano S, Suzuki KT. Exposure, metabolism, and toxicity of rare earths and related compounds. Environ Health Perspect. 1996;104:85-95.
157. Gonzalez V et al. Environmental fate and ecotoxicity of lanthanides: are they a uniform group beyond chemistry? Environ Int. 2014;71:148-57.

158. Pagano $\mathrm{G}$ et al. Health effects and toxicity mechanisms of rare earth elements-knowledge gaps and research prospects. Ecotoxicol Environ Saf. 2015;115:40-8.

159. Rim KT et al. Toxicological evaluations of rare earths and their health impacts to workers: a literature review. Saf Health Work. 2013;4:12-26.

160. USEPA. Toxicological review cerium oxide and cerium compounds. United States Environment Protection Agency. 2009. http://www.epa.gov/iris/toxreviews/1018tr.pdf

161. TERA. Development of reference doses and reference concentrations for lanthanides. prepared for the Bureau of Land Management, National Applied Resource Sciences Center by Toxicology Excellence for Risk Assessment. 1999. http://www. tera.org/Publications/

162. ITER. Report on chemical name: lanthanum carbonate, CAS Registry Number: 587-26-8, Noncancer oral risk values - level 2. International Toxicity Estimates for Risk. https://iter.ctc.com/ publicURL/p_report_12_non.cfm?crn=587-26-8\&type $=$ NCO. Accessed 09Jul 2015.

163. USEPA. Rare earth elements : a review of production, processing , recycling , and associated environmental issues.2012. http:// nepis.epa.gov/Adobe/PDF/P100EUBC.pdf

164. Ono FB et al. Arsenic bioaccessibility in a gold mining area: a health risk assessment for children. Environ Geochem Health. 2012;34:457-65.

165. Toujaguez R et al. Arsenic bioaccessibility in gold mine tailings of Delita. Cuba J Hazard Mater. 2013;262:1004-13.

166. Wei B et al. Rare earth elements in human hair from a mining area of China. Ecotoxicol Environ Saf. 2013;96:118-23.

167. Hao $\mathrm{Z}$ et al. Levels of rare earth elements, heavy metals and uranium in a population living in Baiyun Obo, Inner Mongolia, China: a pilot study. Chemosphere. 2015;128C:161-70.

168. Wang $\mathrm{Z}$ et al. Effects of rare-earth fertilizers on the emission of nitrous oxide from agricultural soils in China. Atmos Environ. 2008;42:3882-7.

169. Li J et al. Effects of the accumulation of the rare earth elements on soil macrofauna community. J Rare Earths. 2010;28:957-64.

170. Cheng J et al. Rare earth element transfer from soil to navel orange pulp (Citrus sinensis Osbeck cv. Newhall) and the effects on internal fruit quality. PLoS ONE. 2015;10:e0120618.

171. Thomas PJ et al. Rare earth elements (REEs): effects on germination and growth of selected crop and native plant species. Chemosphere. 2014;96:57-66.

172. USEPA. Guidelines for ecological risk assessment. United States Environmental Protection Agency; 1998. http://www2.epa.gov/sites/ production/files/2014-11/documents/eco risk assessment1998.pdf.

173. Haley TJ et al. Pharmacology and toxicology of dysprosium, holmium, and erbium chlorides. Toxicol Appl Pharmacol. 1966;8: $37-43$.

174. Haley TJ et al. Toxicological and pharmacological effects of gadolinium and samarium chlorides. Br J Pharmacol Chemother. 1961;17:526-32.

175. Haley TJ et al. Pharmacology and toxicology of terbium, thulium, and ytterbium chlorides. Toxicol Appl Pharmacol. 1963;5:42736. 